パネルディスカッション 


\section{パネルディスカッション 1}

\section{透析患者の重症下肢虚血に対する治療戦略}

座長: 三井 信介 (済生会八幡総合病院 血管外科)

横井 宏佳 (高邦会 福岡山王病院 循環器センター)

\section{PD-1-1 透析患者の下肢閉塞性動脈硬化症による 重症下肢虚血に対する治療戦略}

川崎医科大学 心臟血管外科

○柚木 靖弘、田村 太志、桑田 憲明、田淵 篤、 渡部 芳子、山澤 隆彦、古川 博史、金岡 祐司、

種本 和雄

透析患者の重症下肢虚血に対する治療戦略は，1. 外科的血行 再建術を第一選択肢とする. Goodney score を用いた全身状態で 5 点以上は血管内治療も考慮する. 2. 鼠径䗖帯以下のバイパス には神経ブロックを併用する． 3. 吻合は 7-0 Prolene の後壁パ ラシュート法の連続縫合を用いる。石灰化の強い部位はタング ステンーレニウム合金製 EVERPOINT を使用する．4．外来に て定期的に静脈グラフトのチェックを行い，狭窄等に対し適宜 追加治療を行う. 2010 年 1 月から 2018 年 12 月までの重症虚血 肢手術症例は 66 症例・ 68 肢であった. 透析症例は 20 症例・ 20 肢であった。 10 年以上の透析歴が 10 例 $(50 \%)$ ，糖尿病合併症例 は 16 例(80\%)であった. 透析群は年齢平均 68.6 歳, 男女比 9:11, 非透析群は年齢平均 77.1 歳, 男女比は 33:15 で，年齢に統計学 的有意差を認めた. Goodney score 3 点以上症例は透析例 $85 \%$, 非 透析例 58\%で，透析群で有意に全身状態不良症例が多かった。 Rutherford 5/6 度症例が透析群 $90 \%$ ，非透析群 $71 \%$ であった。 WIfI 分類は透析群 · 非透析群は Stage $1 / 2 / 3 / 4$ が 5/15/40/40\%・6/25/29/40\%で差はなかった. 術後生存率は, 透 析群 1 年 $60 \% \cdot 3$ 年 $43 \% \cdot 5$ 年 $32 \%$ で，非透析群 1 年 $83 \% \cdot 3$ 年 $68 \% \cdot 5$ 年 $55 \%$ に比し不良であった。一次開存率も透析群 1 年 $25 \% \cdot 3$ 年 $17 \% \cdot 5$ 年 $0 \%$ と非透析群 1 年 $57 \% \cdot 3$ 年 $45 \% \cdot 5$ 年 $42 \%$ に比し不良であった。 また amputation free survival も透 析群 1 年 $50 \% \cdot 3$ 年 $44 \% \cdot 5$ 年 $33 \%$ で，非透析群 1 年 $72 \% \cdot 3$ 年 $58 \% \cdot 5$ 年 $52 \%$ に比し不良であった。透析群では非透析群に 比し術後成績は不良であった, 今後術式の改良とともに, 関係各 科と綿密な連携をはかり集学的アプローチにて手術成績の改善 に努めていきたい.

Key words : Peripheral arterial disease, Chronic renal failure

\section{PD-1-2 重症下肢虚血（CLI）を呈する血液透析患} 者に対する自家末梢血 CD34 陽性細胞移植による血 管再生療法

湘南鎌倉総合病院 腎藏病総合医療センター

○大竹 剛靖、小林 修三

【緒言】透析患者では末梢動脈疾患の合併頻度が高く、重症下肢 虚血（CLI）に至ると生命予後に大きく関わる。病変部位は下腿 末梢に多く高度な血管石灰化を伴うため、従来の血行再建治療 （血管内治療や外科的バイパス）では救肢成績には限界がある。 当院では、これら CLI 透析患者に対し自己末梢血由来 CD34 陽 性細胞移植の臨床研究を行い、良好な成績が得られたので報告
する。

【方法】対象は血管造影で下肢動脈の有意狭窄・閉塞が確認さ れ、血管内治療やバイパス術の適応がない、あるいは血行再建を 行っても改善のないCLI 合併血液透析患者。G-CSF $5 \mu \mathrm{g} / \mathrm{kg} 5$ 日間投与後末梢血単核球を回収し、翌日 CD 34 陽性細胞を magnetic beads を用いて磁気的に分離し、虚血肢の下腿から足部 にかけて筋肉内注射し、治療後 1 年間の安全性と有効性を検討 した。

【結果】 6 名 7 肢に細胞移植を施行した (Rutherfor 4 群 2 名、 5 群 4 名、潰痬サイズ $5-35 \mathrm{~mm}$ )。矢の結果、1 年切断回避生存率 (AFS)100\%、CLI から non-CLIへの改善率 83.3\%（治療後 52 週）と著明な効果が得られた。安全性には問題を認めなかった。 5 潰瘍中 3 潰瘍は 12 週以内に治癒し、同時に 6 分間歩行最大歩 行距離、足趾 SPP に有意な改善を認めた。

【結論】no-option の CLI 合併血液透析患者に対する本治療は、安 全に施行でき、臨床的重症度の改善において非常に有用であっ た (Ohtake T, et al: Stem Cells Trans Med 2018: 7:774-782)。今 後、先進医療 B として本治療をさらに多数例で検証する予定で ある。

Key words : hemodialysis, critical limb ischemia

\section{PD-1-3 透析患者 CLI に対する治療戦略}

1 社会医療法人 愛仁会 井上病院 血管外科、2 住友病院 血管内治療センターー

○谷村 信宏 1 、西本 幸弘 2 、大仲 玄明 2 、田中 陽介 2 、 山本 浩詞 2、安宅 啓二 2

【はじめに】当院は透析症例を主に診療しており、それに伴って PAD、特にCLI 症例を多数経験している。透析による重症例が 多いことから従来 EVT firstの方針で行ってきた。しかし、EVT の及では治癒しない症例も多く、外科的血行再建への移行につ いて苦慮することもあるが、原則的には 2 回以上の EVT でも治 癒しない症例については、外科的血行再建を考慮している。

【結果】2013/5月～2019/3 月に経験した透析患者の distal bypass 症例は 63 肢で、年齢 $75.7 \pm 6.7(57-93)$ 、男性 : 女性= $39 ： 24 、 F o n t a i n e$ 分類 $(2 / 3 / 4)=3 / 5 / 55$ 、手術時間 $224 \pm 79$ 分（101-496）であった。麻酔は全身麻醉が基本であるが、神経 ブロック(PNB)を多用して打り、重症例では PNB のみで手術を 行った。一次開存率 (5 年) は $47.6 \%$ 、二次開存率 (5 年) は $75.0 \%$ であり、グラフト狭窄及び閉塞に対しては速やかに EVT または 手術での介入を可能な限り行った。しかし、Cardiovascular disease や感染症といった透析合併症による死亡が多く、大切断 回避生存率(AFS) 1 年 $61 \% 、 2$ 年 $33 \% 、 5$ 年 $23 \%$ と不良であ り、Soga らが 2 年以上生存 $<50 \%$ と報告する 2 YLEscore $\geqq 8$ の 症例が 23 肢（36.5\%）含まれていた。

【考察及び結語】CLI 透析症例の予後は極めて不良であった。 しかし、 distal bypass 自体は体表面の手術で侵襲は高くなく、麻 酔をPNBで行うことでさらなる低侵襲化が可能である。 Distal bypass でしか救肢できない症例に対しては積極的に手術 を行っていきたい。

Key words : hemodialysis, distal bypass 


\section{PD-1-4 透析患者の重症下肢虚血に対する当院の 治療戦略 一 Bypass first は妥当かー}

JA 広島総合病院

○小林 平、濱本 正樹、小澤 優道、原田 拓光

【目的】透析患者の重症下肢虚血は一般に虚血が重度で、広範囲 の壊疽、潰崵を伴うことが多い。全身状態や生命予後不良である ことから EVT が選択されることが多いが、当院では血液供給量 にすぐれる Bypass 術を第一選択としており、その妥当性につい て検討する。

【対象】 2009 年 4 月〜 2019 年 3 月、透析患者の CLIに対して Distal bypass 術を施行した 115 肢（86 例）を対象とした。男性 61 例 $(71 \%)$ 、年齢 $71 \pm 9$ 歳、術前 Rutherford 分類 $4: 6$ 肢、 5 : 64 肢 $(56 \%) 、 6: 45$ 肢 $(39 \%)$ であった。

【結果】全例自家静脈をグラフトとして使用し、97 肢 (84\%) で Non-reversed で血行再建を行い、75 肢 $(65 \%)$ で足関節以遠に 吻合を行った。手術時間は平均 198 分、術中グラフトフローは $18 \pm 16 \mathrm{ml} / \mathrm{min}$ 、術後入院期間は平均 67 日であった。 61 例 $(71 \%)$ が独歩退院し、58 例（67\%）が自宅復帰した。遠隔期追跡期間 は $21 \pm 19$ ヶ月で、グラフト閉塞は 25 例、二次開率は 1 年 $80 \%$ 、 3 年 $72 \%$ であった。 17 例で大切断に至り、大切断回避率は 1 年 $89 \% 、 3$ 年 $82 \%$ であった。遠隔死亡は 45 例で、生存率は 1 年 $76 \% 、 3$ 年 $35 \%$ であった。

【考察】透析の CLI 患者の予後は本検討でも不良であったが、創 の治瘑が得られなければ社会生活も難しい。Bypass の血液供給 量はEVTにまさり、組織欠損の大きい透析患者では有利といえ る。7 割程度の患者で自宅復帰できて抢り、遠隔期 8 割以上の患 者の大切断が回避できていること考慮すると Bypass first は妥 当な治療法といえるであろう。

Key words : Distal Bypass, Critical Limb Ischemia

\section{PD-1-5 透析患者と非透析患者の相違点と術後成 績}

九州大学 消化器 · 総合外科 (第二外科)

○古山 正、吉野 伸一郎、黒瀬 俊、中山 謙、

山下 勝、川久保 英介、森崎 浩一、森 正樹

【背景】透析患者は慢性動脈閉塞症の重症化の要因の一つであ り、動脈の高度石灰化や循環動態の不安定さなどから、血行再建 術の開存性の低下や潰瘍・手術創の難治性を引き起こす。

【対象と方法】 2013 年から 2018 年までに血行再建を行った重症 虚血肢のうち、Rutherford 分類 $5 、 6$ の 97 例 122 肢を対象とし た。血行再建は EVT が 28 肢、バイパスが 94 肢に行われた。術 前併存疾患として透析を伴う HD 群 61 肢と伴わないnonHD 群 61 肢の術後成績について検討した。

【結果】1)HD 群の特徵：HD 群はnonHD 群に比較して、男性、膝 下病変、虚血性心疾患の併存、 $\beta$ ブロッカーや抗凝固薬の内服、 潰瘍の未治瘜死亡が多かった。2) HD 群の成績 : 潰瘍治癒率は HD 群 73.8\%、nonHD 群 86.9\%、大切断率は HD 群 6.6\%、nonHD 群 $4.9 \%$ と、両群間で差を認めなかった。 2 年一次開存率は HD 群 $55.9 \%$, nonHD 群 $73.4 \% 、 2$ 年二次開存率は HD 群 $87.1 \%$ 、nonHD 群 $86.5 \% 、 2$ 年 Amputation Free Survival Rate は HD 群 $61.1 \%$ 、 nonHD 群 $68.2 \%$ と一次開存率の久両群間に有意差を認めた。
2)HD 群の危険因子：潰瘍治癒に関与する因子は HD 群で Rutherford 分類 6、膝下病変、低栄養状態、脳血管障害の併存、 Skin perfusion pressure 上昇不良、nonHD 群で女性、Rutherford 分類 6.SPP 上昇不良であった。生命予後に関する因子は HD 群 で高齢、虚血性心疾患の併存、低栄養状態、nonHD 群で虚血性心 疾患の併存であり、大切断に関与する因子は HD 群でバイパス の開存性、nonHD 群で低栄養状態とバイパスの開存性であった。 【まとめ】透析患者は非透析患者より一次開存率が劣り、死因と しての腸管虚血が特徽的であった。低栄養状態は透析患者の潰 瘍治痹、生命予後、非透析患者の救肢に関与していた。

Key words : HD, CLI

\section{PD-1-6 透析例に対する創傷治癒を目指したバイ パス術の適応と創傷管理}

旭川医科大学 血管外科

○菊地 信介、内田 大貴、宮本 寛之、高橋一輝、

鎌田 啓輔、栃窪 藍、古屋 敦宏、東 信良

【背景】下腿動脈病変に対するバイパス術の適応が見直されてい る今日、透析例に対するバイパス術の妥当性と、創傷治癒に対す る介入の工夫が欠かせない。

【方法】教室にて 2012 年から 2017 年の 6 年間でCLTI を発症 し血行再建を要した 104 例 139 肢を後ろ向きに解析し、生命予 後を見越した血行再建法の妥当性を検討する。

【結果】平均年齢は 67 歳、糖尿病 85 例、冠血行再建歴 57 例、入 院時自力歩行保持例 61 例 $(59 \%)$ であった。術後 1 年大切断回 避生存率は $81 \% 、 3$ 年で $32 \%$ でった。SPINACH Registry favorability score 算出すると、Favors EVT(Q1)は 67 肢 (48\%) と半数を占めた一方で、Favors surgery (Q4)は 4 肢 $(3.0 \%)$ のみに留まったが、実際には 116 肢 (83\%) にバイパス術が施行 された（足部動脈バイパスが主で、血管内治療 (EVT)からコン バートが 13 肢含まれる)。麻醉法は全身麻酔から神経ブロック に移行し、その適応は 2017 年に $71 \%$ にまで達した。残りの 23 肢は主に下腿動脈病変に対する EVT であった。骨露出例や広範 組織欠損例には MRI による骨評価を行い、適切な小切断を行う ことで、創傷治癒率は $78.2 \% 、 1$ 年で $91.2 \%$ に至った。 EVT 症 例に限っては、WIfI 分類ステージ 4 こそバイパス例と同等数で あったが、ステージ 1-2 の軽症例により多く選択され、6 か月時 点の創傷治癒率は約 $68 \%$ と比較的良好であった。

【結語】透析例の CLTIに执いて、不良な背景因子からバイパス 適応例は一見限定的となるが、神経ブロック麻醉を用いること でその適応は大幅に広がる。適切な創部管理を行うことで、高率 に生存が期待できる 1 年以内に創傷治㾍が達成され、組織欠損 の軽度の症例ではEVT で完全血行再建が得られれば治癒を期 待できる。

Key words : gtr5431 


\section{パネルディスカッション 2}

\section{肺高血圧に対する治療戦略}

座長: 荻野均 (東京医科大学 心臟血管外科)

田邊＼cjkstart信宏（千葉県済生会習志野病院）

\section{PD-2-1ＢPA 治療後の CTEPH 患者においてリオ シグアトは運動負荷による血行動態反応を改善する 東北大学 循環器内科学}

○杉村 宏一郎、青木 竜男、建部 俊介、福井 重文、 山本 沙織、佐藤 遥、紺野 亮、照井洋輔、下川 宏明 【背景】Guanylate cyclase 刺激薬であるリオシグアトは、慢性血 栓塞栓性肺高血圧症 (CTEPH) に適応を有する NO 経路に関連 した肺血管拡張薬である。バルーン肺血管形成術 (BPA) 治療後 の CTEPH 患者にリオシグアトを継続して投与すべきか否かは 定説がない。本研究では、運動中の血行動態にリオシグアトがど のような影響を与えるか、無作為比較研究を行った。

【方法と結果】 2015 年 9 月から 2018 年 4 月までの間に、BPAを 施行して肺血管拡張薬の中止後も平均肺動脈圧が $30 \mathrm{mmHg}$ 未満 の CTEPH 症例を対象とした $(20$ 症例、平均年齢 65 歳、女性 18 名)。右心カテーテルは、右内頸静脈からスワンガンッカテーテ ルを挿入し、臥位でエルゴメーターを用い、運動負荷を行い、運 動時の血行動態を評価した。同時に呼気ガス分析を施行し、直接 Fick 法による心拍出量の計測も行った。初回のカテ後、対象をリ オシグアト投与群と非投与群に無作為化し、6 か月後に同様の検 查を行った。リオシグアト投与群では、運動中の PVR 上昇率は 68\%から 18\%に低下し (P=0.04)、mPAP-CO slope は 14.6 から 9.4 に低下した $(\mathrm{P}=0.02)$ 。これに対して、非投与群では $\mathrm{PVR} 、$ mPAP-CO slope の変化は認められなかった。

【結語】BPA 治療後の CTEPH 患者において、リオシグアトは運 動中の血行動態反応を改善した。

Key words : CTEPH, BPA

\section{PD-2-2 高安肺動脈炎を伴う肺高血圧症の外科治 療経験}

${ }^{1}$ 大阪健康管理センター、 2 藤田医科大学 心臟血管外科 ○安藤 太三 1,2

【目的】高安動脈炎は大動脈及びその主要分枝や肺動脈に炎症性 壁肥厚をきたし、その結果として狭窄、閉塞または搪張病変を来 す原因不明の非特異的大型血管炎である。今回、高安肺動脈炎に より慢性の肺高血圧症を呈した症例に対して外科的治療を行っ た経験を報告する。

【症例】 2018 年までに大阪、名古屋及び一宮の 3 病院での手術症 例は 11 例、年齢は 49-74 歳(平均 58 歳)、男性/女性 $=4 / 7$ 、狭窄 性病変/搪張性病変 $=8 / 3$ 、全例で右心カテーテル検查にて平均 肺動脈圧は $30 \mathrm{mmHg}$ 以上の肺高血圧を呈していた。狭窄性病変 の 8 例では主肺動脈の閉塞や狭窄を、拡張性病変の 3 例では著 明な主肺動脈の拡張と主肺動脈の壁在血栓、区域動脈の閉塞所 見を認めた。

【手術方法】人工心肺使用に上る超低体温体外循環下に、狭窄性 病変の 8 例には狭窄部内膜摘除とパッチ拡大術を施行、2 例では
バイパス術を追加した。拡張性病変の 3 例には通常の両側肺動 脈血栓内膜摘除術と左主肺動脈縫縮術を施行した。

【手術成績】狭窄性病変の 8 例では平均肺動脈圧 $41 \rightarrow 20 \mathrm{mmHg}$ と著明に低下した。拡張性病変の 3 例では 1 例で残存肺高血圧 症を認めたが、11例の全例で症状は軽快して退院となった。

【結論】高安動脈炎は時に肺動脈への関与を認めるが、多くが狭 窄に伴う肺高血圧による右心負荷である。狭窄性病変は主肺動 脈に生じることが多く、外科治療が非常に有効である。拡張性病 変は稀であるが、主肺動脈拡張に伴う血流低下により多量の血 栓が肺動脈内に形成されたと考えられ、血栓内膜摘除により臨 床的に良好な結果を得た。高安肺動脈炎による肺小動脈病变は 不明であり、残存肺高血圧を呈する症例では長期的な内科治療 が必要である。

Key words : Takayasu arteritis, Pulmonary hypertension

\section{PD-2-3 肺高血圧の診断治療を基礎からもう一度 考える}

国際医療福祉大学医学部循環器内科

○田村 雄一

肺高血圧症は特定疾患である肺動脈性肺高血圧症 $(\mathrm{PAH})$ と慢性 肺血栓塞栓性肺高血圧症(CTEPH)のほかに、呼吸器疾患に伴う 肺高血圧症や左心疾患に伴う肺高血圧症が存在する。肺高血圧 症として診療する大多数のケースは、肺循環障害を伴わない呼 吸器疾患や左心疾患に伴うものである。しかし近年ではこれら の基礎疾患と肺循環障害がオーバーラップしている場合があ り、診断時に十分注意しなければ治療機会を冕してしまいかね ない。本セッションでは、肺動脈性肺高血圧症の現在の治療デー タだけではなく、実際に診療を行う上で、どのタイミングで循環 器内科もしくは PH 専門医に相談したらよいかなどに関しての ディスカッションを行い、治療可能なケースを見落とすことが なくなるような臨床的視点を考えていきたい。

Key words : pulmonary hypertension, medical treatment

\section{PD-2-4 慢性血栓塞栓性肺高血圧症に対する肺動 脈バルーン形成術}

千葉大学大学院 医学研究院 呼吸器内科学 ○杉浦 寿彦

慢性血栓塞栓性肺高血圧症 (Chronic thromboembolic pulmonary hypertension；CTEPH）は器質化した血栓が肺動脈を狭窄·閉塞 することで肺高血圧症を引き起こす疾患である。早期に適切な 加療を行わなければ予後不良の疾患である。治療法に関しては 従来から外科的な治療である肺動脈血栓内膜摘除術 (Pulmonary endarterectomy；PEA）が標準療法として行われていた。しい この手術には高度な技術と経験が求められ、特に本邦では可能 な施設が限られていた。また合併症などが理由で手術不能とな る症例が少なからず存在していた。一方でバルーンカテーテル によって血栓によって狭窄・閉塞した肺動脈を広げる治療法 (肺動脈バルーン形成術：Balloon pulmonary angioplasty; BPA）は今世紀に入ってから試みられ、特に 2008 年頃から本邦 で積極的に施行され始め、近年良好な成績が報告されている。当 院では従来は CTEPH の治療はPEAを中心に行ってきたが、 
2013 年から BPA も症例によっては施行している。CTEPH に 対する治療としてはこれ以外に特異的肺動脈薬によるいわゆる 内科治療も今世紀に入って行われているが、PEA、BPA、内科 的治療のどれを選択するかまた組み合わせていくかの判断が今 後重要になっていくと考えられる。今回はBPAの治療の実際に ついて当院での経験を提示しながら、BPA を含めた CTEPHの 治療戦略について議論をしていきたいと考えている。

Key words : CTEPH, Balloon pulmonary angioplasty

\section{PD-2-5 慢性血栓塞栓性肺高血圧症 (CTEPH) に対 する最近の治療戦略}

1 東京医科大学 心藏血管外科、 ${ }^{2}$ 東京医科大学 循環器内科 ○鈴木 隼 1 、中野 優 1 、松本 龍門 1 、加納 正樹 1 、

丸野 恵大 1 、岩堀 晃也 1 、高橋 聡 1 、岩橋 徹 1 、

神谷 健太郎 1 、福田尚司 1 、西部 俊哉 1 、荻野 均 1 、

山下 淳 2 、近森 大志郎 2

慢性血栓塞栓性肺高血圧症 (CTEPH) に対する治療は、ガイド ライン上も実臨床においても肺動脈内膜摘除術 (PEA) が根治的 であり、PEA により一度に肺動脈全体の血流クリアランスが可 能で, 肺高血圧症 (PH) や低酸素血症の著明な改善が得られる . また、最近では正確な病態の把握、手術手技の向上、経験の蓄 積により国内外において PEA の成績は著しく向上している。一 方、近年の経皮的肺動脈形成術 (BPA) や薬物治療も著しく発展 してきており、有効性が報告され注目されている。主要施設を中 心に CTEPH チームが形成され, CTEPH 治療体系も変化して きており、CTEPH チームカンファレンスにより, PEA の適応外 となった症例に BPA もしくは薬物治療が選択されるのが，ガイ ドライン上推奨される一連の流れである。当院ではPEA 術後 の遺残肺高血圧 $(\mathrm{PH})$ 症例に追加 BPA を施行する hybrid 治療で 良好な成績が得られており、また術前にBPAを施行した症例も 経験している. 2012 年-2018 年までの 81 例にPEAを施行. こ のうち, ハイリスク症例を中心にBPA 先行 PEA は 7 例で, 逆 にPEA 後の遺残 PHに対し 29 例にBPAを追加施行した。そ の結果, $\mathrm{PEA}$ 後の病院死亡率は $1.2 \%$ と良好で, かつ $\mathrm{BPA}$ 追加 により良好な QOL が得られている。このように CTEPH チー ムによる集学的診療が可能となり, 症例, 病変, 経過に見合った 適切な治療法をいかに選択, 組み合わせていくかが今後より重 要となってきている. 更に, 救命からより良い $\mathrm{QOL} へ と$ CTEPH 治療全体の最終ゴールをどこに置くかも, 各種治療の成 績が安定して中での今後の検討課題である.

Key words : CTEPH, PEA

\section{パネルディスカッション 3}

TEVAR で胸腹部大動脈瘤治療に対する治療戦略は 変わったか?

座長: 志水 秀行 (慶應義塾大学 心臓血管外科)

小櫃由樹生（国際医療福祉大学三田病院 血管外科）

PD-3-1 腹部臓器血行再建を必要とする胸腹部大 動脈瘤治療における従来の人工血管置換と abdominal debranched TEVAR の比較検討

岐皁県総合医療センター 心臓血管センター

○森 義雄、後藤 芳章、堀尾 俊太郎、松野 幸博、

梅田 幸生

胸腹部大動脈瘤に対する開胸・後腹膜アプローチでの人工血管 置換は、高侵襲であり術後合併症頻度が高い。高齢者、再手術例 が増加する中、当院では積極的に開腹のみによる abdominal debranched TEVAR を施行している。腹部分枝（腹腔動脈 $(\mathrm{CA})$ ・上腸間膜動脈 $(\mathrm{SMA}) \cdot$ 左右腎動脈 $(\mathrm{L}, \mathrm{RRA}))$ を再建し た開胸・後腹膜アプローチによる人工血管置換 (C 群) と開腹の みによる abdominal debranched TEVAR ( $\mathrm{T}$ 群) の臨床成績を比 較検討した。C 群は 7 例 (年齢 $60 \pm 9$ 歳,男 6,女 1 , 真性 4,解離 $3, H D 1$, 緊急 1,開腹歴 1 例,Japan Score: 30 日死亡 $9 \pm 6$ 、主要合併 症 $34 \pm 8 \%$ )、補助手段として人工心肺を使用し 4 分枝付き胸腹 部大動脈瘤用人工血管 (Coseli,Gel-Weave2,J-graft5 例) を施行 した。 $\mathrm{T}$ 群は 7 例 (年齢 $70 \pm 7$ 歳 $(\mathrm{P}<0.05)$, 男 6, 女 1 , 真性 5 ,解 離 2,HD1,開腹歴 5 例,Japan Score:30 日死亡 $13 \pm 6 \%(\mathrm{P}<0.05)$, 主要合併症 $37 \pm 10 \%) 、$ inlow 右腸骨動脈として人工血管 (Fusion) を吻合後、SMA,CA,RA へ debranch 後 TEVAR 施行し た。RA 再建の視野が不良場合は腎虚血時間短縮のため、 VORTEC 法による RA 再建を 4 例に使用した。手術時間:C 群 $665 \pm 138$, T 群 $625 \pm 142$ 分、術中輸血:C 群 MAP19 \pm 3 , FFP21 \pm 10 ,Plt26 \pm 10 単位、T 群 MAP5 $\pm 4, \mathrm{FFP} 7 \pm 10$, $\mathrm{Plt} 3 \pm 8$ 単位 $(\mathrm{P}<0.05)$ 、術後気管捙管時間: C 群 $150 \pm 125, \mathrm{~T}$ 群 $12 \pm 22$ 時間 $(\mathrm{P}<0.05)$ 、術後 ICU 滞在日数: C 群 $20 \pm 20, \mathrm{~T}$ 群 $6 \pm 4$ 日、在院死亡: $\mathrm{C}$ 群 1 例 (急性解離性瘤破裂例), $\mathrm{T}$ 群 2 例 (穿 孔性腹膜炎、弓部大動脈破裂) 、対麻痺: $\mathrm{C}$ 群 2 例 (28\%)、 $\mathrm{T}$ 群な し。

【結語】開腹による abdominal debranched TEVAR は、手術時間 は要するが、従来の人工血管置換より輸血量が少なく、術後気管 挿管時間を短縮し、対麻痺の発生はなかった。

Key words : thoracoabdominal aneurysm, abdominal debranched TEVAR

\section{PD-3-2 胸腹部大動脈瘤に対する人工血管置換術 - 術前 Frailty からの検討 慶應義塾大学 医学部 外科 (心臟血管) \\ ○伊藤 努、飯尾 みなみ、浅原 祐太、金山拓亮、 橋本 崇、船石 耕士、松尾 健太郎、秋山 章、 \\ 川合 雄二郎、赤松 雄太、高橋 辰郎、木村 成卓、 \\ 山崎 真敬、志水 秀行 \\ 【目的】胸腹部大動脈瘤に対する人工血管置換術は術野が広範囲 におよび侵襲性が高い。治療後の生活の質を考慮し近年 Frailty}


の概念が浸透しつつある。今回 Frailty による術前リスク評価よ り本術式の妥当性を検討した。

【方法】 2005 年 1 月から 2018 年 12 月までに胸腹部大動脈瘤に 対し人工血管置換術を施行した連続 82 症例の内、後方視的に術 前 Frailty を評価し得た 50 例 (男性 33 例、年齢中央值 65 歳) 対象とした。真性 18 例、解離性 30 例、感染性 2 例であり、破裂 症例 3 例、緊急手術 2 例であった。手術部位は Crawford 分類で I 型 1 例、II 型 19 例、III 型 22 例、IV 型 6 例、いわゆる V 型は 2 例であった。Frailtyは年齢 $\geqq 70$ 歳、body mass index $<$ $18.5 \mathrm{~kg} / \mathrm{m} 2$ 、anemia(男性 $\mathrm{Hb}<13.0 \mathrm{~g} / \mathrm{dl}$ 、女性 $\mathrm{Hb}<12.0 \mathrm{~g} / \mathrm{dl}$ )、 creatinine $>1.2 \mathrm{mg} / \mathrm{dl}$ 、 hypoalbuminemia $<3.5 \mathrm{~g} / \mathrm{dl}$ 、脳梗塞の既往、 psoas muscle index (腰椎 L3 レべル大腰筋横断面積を身長の 2 乗で除した值) 平均 4 分位数以下、の 7 項目より 3 項目以上で Frailty と定義した。

【結果】Frailty 症例は 15 例 (男性 10 例) であった。手術死亡は 2 例 (多発塞栓、術後肺炎、Frailty 1 例、sarcopenia 2 例)。術後 自宅退院は 38 例、リハビリ転院は 10 例であった。術後脊髄障害 はなし。術後生存率は 1 年 $92 \% 、 5$ 年 $84 \%$ 、大動脈関連死亡は 4 例で回避率は 5 年で $90 \%$ であった。Frailty 群と非 Frailty 群 で比較すると術後 5 年生存率はそれぞれ $63 \%$ 、93\%、大動脈関 連死亡回避率は 5 年で $86 \%$ 、97\%であり有意差を認めた。 sarcopenia 症例、貧血症例は有意に周術期リスクが高い結果で あった。

【結語】胸腹部大動脈瘤に対する人工血管置換術は良好な成績で あった。Frailty 評価は人工血管置換術のリスク評価に有益と考 えられた。

Key words : Frailty, thoracoabdominal aorta

\section{PD-3-3＼cjkstart腹部デブランチ TEVAR による胸腹部大 動脈瘤治療}

大分大学 心臓血管外科

○首藤 敬史、穴井 博文、和田 朋之、岡本 啓太郎、 川野まどか、梅野 惟史、内田 かおる、小島丈典、

木津 謙也、宮本 伸二

【目的】胸腹部大動脈瘤の治療は大血管治療の中でも依然として 課題の多い領域である。高齢化社会を迎えた本邦では高齢の患 者も増加しており、如何に治療をおこない手術成績を向上させ るかに取り組んできた。当院でおこなってきた腹部デブランチ TEVAR を検討した。

【対象】胸腹部大動脈瘤に対して 2007 年から 2018 年までにおこ なった腹部デブランチ TEVAR 74 例を対象とした。

【結果】腹部デブランチの標準術式は腹部大動脈を人工血管置換 し、その胴体から脚に 4 分枝人工血管を吻合する。その枝で腹部 4 分枝(左右腎動脈、上腸間膜動脈、腹腔動脈)にバイパスをおこ なう。その後、二期的に TEVAR をおこなうことを基本とした。 平均年齢は 73(44-89)歳で、男性 51 例、女性 23 例。真性瘤 54 例、 解離 20 例。腹部デブランチの平均手術時間は 527 分、ICU 滞在 期間は 3.5 日、TEVAR までの平均待機期間は 31 日であった。入

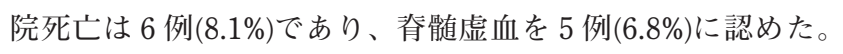
TEVAR の待機中に 5 例(6.8\%)の破裂を経験した。Endoleak 18 例(24\%)に認め、6 例に追加治療をおこなった。遠隔期に 5 例
(6.8\%)が維持透析となった。腹部デブランチ TEVAR が完了した 患者の遠隔期の大動脈関連死は 3 例(4.5\%)であった。

【考察】腹部デブランチ手術自体は低侵襲とは言えないが、高齢 者でも耐えられる手術である。TEVAR 完了までは瘤破裂のリ スクが常に存在することを念頭におく必要がある。今のところ 腹部デブランチ TEVAR は高歯者やハイリスク患者に対して推 奨される治療である。若年者に対する hybrid 治療は議論の余地 はあるが、endoleakによる遠隔期の再治療回避と腹部分枝への バイパスの長期開存が維持できれば推奨される治療になりうる と考える。

Key words : thoracoabdominal aortic aneurysm, renovisceral debranching TEVAR

\section{PD-3-4 胸腹部大動脈瘤に対する Open Surgery とSecondary TEVAR による Hybrid 手術での治療 戦略}

神戸市立医療センター中央市民病院 心臓血管外科

○中村 健、吉田 壮志、藤井 浩史、吉田 一史、

小泉 滋樹、坪田 秀樹、石上 雅之助、小山 忠明

【背景】全弓部大動脈置換術(TAR)後の胸腹部大動脈瘤手術では 肺の癒着により中枢の確保が困難な症例がある。今回、当施設で $\mathrm{TAR}$ 後の胸腹部大動脈瘤に対し、横隔膜レベル前後までの胸腹 部大動脈置換術を実施後に、残存瘤に二期的 TEVAR を行った 症例を 3 例経験した。その治療戦略を考察する。[症例 1] 44 歳女 性。Malfan 症候群。Bentall · MVR - TAR · 下行大動脈置換術後。 胸腹部大動脈瘤で最大短径 $62 \mathrm{~mm}$ 。一期的に胸腹部大動脈置換術 を試みるも肺の高度癒着で断念。胸腹部大動脈置換術を先行し、 二期的に TEVAR を施行。術後 CT では問題なし。対麻痺もな し。呼吸トラブルで、長期間の入院となったが、第 126 病日に自 宅退院。[症例 2] 65 歳男性。IIIb 型大動脈解離に対して TAR 後。 残存した解離性大動脈瘤が最大短径 $56 \mathrm{~mm}$ で、拡大傾向あり。胸 腹部大動脈置換術を先行し、二期的 TEVAR を施行。術後 CT で 人工血管吻合部は問題ないが、typeII エンドリークあり。対麻痺 なし。第 34 病日に自宅退院。[症例 3] 81 歳女性。弓部大動脈瘤 に対し、TAR 後。大動脈解離を発症し瘤径拡大傾向で最大短径 $56 \mathrm{~mm}$ 。胸腹部大動脈置換術を先行し、二期的 TEVAR を施行。第 1 病日に対麻痺を発症。春髄保護治療で第 2 病日に軽快。術後 CT ではエンドリークなし、人工血管吻合部も問題なし。離床に 時間を要し、第 68 病日にリハビリ転院。

【考察】1 例では早期対麻痺を発症したが、早期に改善。いずれの 症例も大動脈関連イベントはなし。肺の高度癒着が予想される TAR 後の胸腹部大動脈瘤症例においては、Hybrid 手術による治 療は有効と考える。但し、TEVAR の適切なタイミングや長期成 績は不明であり、今後症例を重ねて、更なる検討が必要である。 Key words : TEVAR, Hybrid 


\section{PD-3-5 胸腹部大動脈瘤に対する腹腔動脈被覆を 伴う TEVAR の有効性}

名古屋大学医学系研究科 血管外科

○池田 脩太、川井 陽平、鶴岡 玩也、榊原 昌志、 飯井 克明、高橋 範子、杉本 昌之、新美 清章、

児玉 章朗、坂野 比吕志、古森 公浩

【目的】胸部大動脈瘤に対するステントグラフト内插術(Thoracic Endovascular Aortic Repair 以下 TEVAR)は低侵襲で有効な 治療法であるが、腹部分枝を巻き込んだ胸腹部大動脈瘤に対し ては、市販のステントグラフトによる治療は困難である。一方、 腹腔動脈(Celiac artery 以下 CA)を被覆しランディング長を延 長することにより一部の胸腹部大動脈瘤の治療が可能となる。 当院での胸腹部大動脈瘤に対する $\mathrm{CA}$ 被覆を伴った TEVAR の 有効性について検討する。

【方法】 2008 年 10 月から 2019 年 5 月までに TEVARを行った 379 例中 $\mathrm{CA}$ 被覆を行った 17 例(4.5\%)を対象とした。

【結果】男性 16 例 $(94.1 \%) 、$ 平均年齢 $71 \pm 13$ 歳。CA 被覆のみが 9 例(52.9\%)で塞栓を行ったものが 8 例(47.1\%)であった。上腸間 膜-腹腔動脈間の交通を術前 CT で確認できたのは 8 例 $(47.1 \%)$ で、5 例 $29.4 \%)$ は術中造影で確認した。 $\mathrm{CA}$ 直上留置では平均 $6.1 \mathrm{~mm}$ のランディング長であったが、 $\mathrm{CA}$ 被覆により平均 $19.3 \mathrm{~mm}$ のランディング長の延長が得られた。術後合併症として 対麻疩 2 例、末梢塞栓 2 例であった。末梢塞栓が発生した 2 例と も脾梗塞を発症し、 1 例は膵炎も発症したがいずれも保存的に改 善した。退院時エンドリークは Ib が 1 例、II が 3 例であった。遠 隔期成績 (経過観察期間中央值：34 ケ月）は、経過観察中の死亡 が 2 例、瘤関連死はなかった。瘤径拡大を 2 例に認め、先のうち 追加治療を要したのは Ib エンドリークを発症した 1 例のみで あった。

【結論】CA 被覆による合併症はいずれも軽症で、術後のエンドリ 一クや追加治療の頻度も少なく、有効な治療法であると考元ら れる。しかしながら、CA 被覆によって得られるランディング長 は十分とはいえず、厳重な経過観察が必要である。

Key words : TEVAR, celiac artery embolism

\section{パネルディスカッション 4}

\section{CAT:cancer associated thrombosis に対する 治療戦略}

座長：保田 知生（がん研有明病院 医療安全管理部） 松本 拓也 (国際医療福祉大学 血管外科)

\section{PD-4-1 当院における CAT(Cancer Associated Thrombosis) の現状と対策 \\ 洛和会音羽病院 脈管外科 \\ ○武田 亮二}

【はじめに】2011 年以降の院内VTE の現状と Cancer Associated Thrombosis (以下 CAT) の発生頻度について検討 し、CAT 対策チーム活動について報告する。

【対象】 2011 年 1 月から 2019 年 3 月まで 7 年間、当院で診断さ れたVTE 中 CATについて検討した。

【結果】全 VTE 中、CAT は 200/1491 中枢型 71 例、未梢型 129
例、肺塞栓（以下 PE）合併 14 例であった。VTE の原因腫瘍と しては、大腸癌が 57 例、胃癌が 28 例、肺癌 26 例 膵癌 19 例 であった。CAT 発見から死亡まで 3 ヶ月以内の患者は 58 例 (29\%) 血栓死亡 2 例であった。

【考察】諸家の報告ではVTE 中 CAT の占める割合は $30 \%$ 程度 である。当院は整形外科、外科の VTE スクリーニングを 2 行な って抢り、無症候性 VTE が多く発見されるためCAT の割合は 少ない傾向にある。CAT のリスク評価は Khorana スコアが有名 であるが、作成が 2007 年と古く、BMI35 以上がリスク因子に含 まれるなど本邦の現状にそぐわない。当院では Khorana スコア を参考に化学療法開始時の薬剤師によるチェックに CAT 早期 発見を本年度から組み込んみ、院内の啓蒙につながっている。

【まとめ】癌治療の進歩によって生存期間も延長し、高齢の担癌 患者も増加している。今回の検討で、現状では CAT の多くがタ 一ミナルステージで発見され、今までの VTE 予防では不十分で ある。LMWH がCAT 予防で使用できない現状では、CAT 対策 チームによる早期発見が鍵となると思われる。

Key words : CAT, early detection

\section{PD-4-2 院内発症 CAT に対する治療戦略}

${ }^{1}$ 国際医療福祉大学病院 循環器センター 血管外科、2 国際 医療福祉大学 医学部血管外科学（成田）

○村上 厚文 ${ }^{1,2}$ 、洞口 哲 1 、山下 勝 ${ }^{1}$ 加藤 盛人 1 、

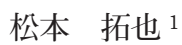

【はじめに】悪性腫瘍はVenous Thrombo Embolism (以下 VTE) の重要な伦険因子で、 cancer associated thrombosis(CAT)として 注目されている。

【対象と方法】 2006 年 1 月以降の院内発症 VTE 113 例中、基礎 疾患に悪性腫瘍を有した 2019 年 4 月までの 33 例を対象とし た。発症の契機、発症部位、PE 合併の有無、治療法、予後つい て検討した。

【結果】 33 例の背景は卵巣癌: 6 例、肺癌: 5 例、大腸癌と子宮癌:4 例、胃癌、膵癌: 3 例、食道癌、脳腫瘍、乳癌,腎孟癌、膀胱癌、前 立腺癌、卵管癌、多発性骨髄腫がそれぞれ 1 例ずつであった。プ ロテイン C,S の欠損症、抗リン脂質抗体症候群を合併した 3 例 を除く 30 例は広義の Trousseau 症候群と診断、1 例で広範な脑 梗塞を合併した。主な契機は D ダイマー上昇と下肢腫脹で、発症 時 D ダイマー值は平均 $20.6 \pm 19.8$ であった。PE 合併は 20(60.6\%)例であった。治療はへパリン、ウロキナーゼ、ワルファ リンなどの組み合わせから近年 DOACへの移行が急増し、 2015-2018 年は DOAC の single drug approach が 43.8\%に達し た。逆に IVC-f(フィルター)使用率は低下、2016-2018 年では CAT でも使用例が認められなかった。また血栓溶解療法開始 後、血栓症が増悪した症例を 2 例認めた。現時点で死亡は 11 例 だがVTE が直接死因と考えられた症例は認められなかった。

【まとめと考察】IVC-f や血栓破研打よび溶解療法が減少し、へ パリンから DOAC への移行、DOAC 単独使用が広く適用されて いた。低分子へパリンに比べ DOAC は、再発率の有効性は認め られるが、大出血や臨床的に重要な非大出血は増加するとの報 告もあり、また抗がん郕や抗不整脈との併用に注意すべき点も 多く、中、長期成績の注意深い追跡が重要と考えられる。 
Key words : VTE, CAT

\section{PD-4-3 化学療法を併用する CAT 患者への抗凝 固療法}

東京医科大学 心藏血管外科

○神谷 健太郎、西部 俊哉、中野 優、松本 龍門、 加納 正樹、鈴木 隼、岩堀 晃也、丸野 恵大、

高橋 聡、岩橋 徹、福田 尚司、荻野 均

【目的】CAT (cancer associated thrombosis) 患者に、抗凝固療 法の適応、薬剤選択や投与期間には難渋する。特に、原疾患に対 する化学療法を併用する場合にはさらに苦慮する。今回、化学療 法を併用している CAT 患者への抗凝固療法について報告する。 【対象】 2015 年 1 月-12 月の 1 年間、新規 VTE を発症した悪性 疾患患者を対象とし、後向きに調査した。

【結果】 2015 年の全血管エコー検査数は 1398 症例中、悪性疾患 を合併していた患者は 21 例（1.5\%、男：女 $5: 16,69.1 \pm 13.1$ 歳)。化学療法を併用したCAT 患者は 14 例 $(66.7 \%$ 、男 : 女 $4: 10,65.2 \pm 10.7$ 歳)。平均 Stage 3.1 期(Stage I/II/III/IV : $2 / 2 / 2 / 7)$ 。手術治療 8 例、放射線治療 8 例が併用されていた。 VTE 診断後の平均観察期間は 560.6 491.8 日。死亡症例は 9 例 (64.3\%)、全て悪性疾患による死亡であった。VTE 関連死亡な し、抗凝固療法に伴う出血性合併症なし。Kaplan-Meier 曲線よ り、一年生存率は $48.2 \%$ 、二年生存率は $32.1 \%$ であった。抗凝固 薬を 11 例(78.6\%)に施行された。ワルファリン 2 例(14.3\%)、 DOAC 9 例(64.3\%)、無治療 3 例(21.4\%、高齢 1、StageIV 2)。選 択した DOAC は、全例 Edoxaban。投与中止症例は、ワルファリ ン 1 例（コントロール不良 1)、DOAC 2 例(胸腔穿刺 1 、内服困 難 1)。平均生存期間は、ワルファリン 694.0 日、DOAC 679.4 日、 無治療 115.0 日。抗凝固薬の平均投与期間は、ワルファリン 411.5 日(57.5\%)、DOAC 483.2 日(70.2\%)であった。

【結語】化学療法を併用する多くの CAT 患者は、予後不良であっ た。化学療法を併用する CAT 患者への抗凝固療法は、大きな合 併症もなく安全に施行し、特にDOAC は終末期まで使用可能で あった。

Key words : CAT, DOAC

\section{PD-4-4 癌関連静脈血栓塞栓症に対する治療方針}

1 浜松医療センター 血管外科、2 浜松医科大学 第二外科. 血管外科

○山本 尚人 1 、海野 直樹 1,2 、露木 肇 1,2 、犬塚 和徳 2 、 佐野 真規 2 、片橋 一人 2、矢田 達朗 2 、嘉山 貴文 2 、 山中 裕太 $^{2}$

【諸言】癌治療成績の向上などに伴い、癌関連静脈血栓症 $(\mathrm{CAT})$ に 遭遇する機会は増え、管理の重要性は増している。当科での CAT 治療方針を発症場所別に検討した。

【対象と方法】 2005 年〜2018 年に経験した VTE7 25 人のうち活 動性の癌を合併していた 322 人(44.4\%)を対象とした。CAT 発症 場所を、院外(非周術期)、院内(非周術期)、術後、術前に分け、深 部静脈血栓症(DVT)や肺血栓塞栓症(PTE)の症状と治療方法(非 経口抗凝固の有無、経口抗凝固の有無、下大静脈フィルター (IVCF)の有無)を検討した。
【結果】男性 166 人、女性 156 人、平均年齢 66.1 歳。発症場所は 院外 124 人、院内 70 人、術後 91 人、術前 37 人。有症状 DVT の頻度は院外 $49.1 \%$ 、院内 $30 \%$ 、術後 $16.5 \%$ 、術前 $8.1 \%$ 。有症状 PTE の頻度は院外 $13.7 \%$ 、院内 $12.9 \%$ 、術後 6.6\%、術前 $10.8 \%$ 。 CAT 発症後の非経口抗凝固薬使用ありの頻度と強度は、院外 57.3\%(治療量 85.9\%、予防量 $14.1 \%$ )、院内 $54.2 \%$ (治療量 $84.2 \%$ 、 予防量 $15.8 \%$ )、術後 $75.8 \%$ (治療量 $63.7 \%$ 、予防量 $36.2 \%$ )、術前 86.5\%(治療量 $34.4 \%$ 、予防量 $65.6 \%$ )。CAT 発症後の経口抗凝固 薬使用ありの頻度と強度は、院外 $73.4 \%$ (治療量 $96.7 \%$ 、予防量 3.3\%)、院内 $51.4 \%$ (治療量 $83.3 \%$ 、予防量 $16.7 \%$ )、術後 56.0\%(治 療量 $90.2 \%$ 、予防量 9.8\%)、術前 $27.0 \%$ (治療量 10\%、予防量 90\%)。 IVCF 使用ありは、院外 $7.3 \%$ 、院内 $4.3 \%$ 、術後 $1.1 \%$ 、術前 $16.2 \%$ 。 症候性 DVT 再発を院外の 2 人 $(0.6 \%)$ に、大出血を 3 人 $(0.9 \%$ 、院 外 1 人、院内 1 人、術前 1 人)に認めた。

【考察】癌患者の置かれている血栓進展のリスクや出血のリスク は患者の状態や癌の状態により大きく異なる。それぞれの患者 に応じた管理が望まれる。

Key words : venous thromboembolism, cancer

\section{PD-4-5 がん関連血栓症として発症した静脈血栓 塞栓症に対する warfarin と DOAC の比較検討}

東北大学病院 総合外科

○後藤 均、赤松 大二朗、菅原 宏文、土田 憲、 吉田 良太朗、梅津 道久、鈴木 峻也、堀井晋一良、 高橋 宏和、小笠原 紀信、龟井 尚

【目的】悪性腫瘍に伴うVTE の抗凝固療法は治療域の狭さから コントロールが難しいと言われる。当施設で経験した症例を対 象に warfarin と DOAC を比較検討することを目的とした。

【対象・方法】 2011 年-2018 年に当施設における悪性腫瘍を伴う 初発の VTE 患者のうち、warfarin またはDOAC を投与された 患者 144 例を対象とし診療録をもとに後ろ向き調査を行った。

【結果】Warfarin を投与された 79 例のうち TTR が $30 \%$ 未満で あった 21 例を除外し、残りの 58 例を warfarin 群（平均年齢 62.6 歳、女 44 例、平均 TTR : $61 \%$ )、DOAC 投与の 65 例を $\mathrm{DOAC}$ 群 (平均年齢 64.7 歳、女 47 例、投与薬 : edoxaban 53、そ の他 12）とし比較検討した。原疾患は warfarin 群では婦人科系 癌 31 例、消化器系癌 9 例、その他 18 例、DOAC 群では婦人科 系癌 34 例、消化器系癌 7 例、その他 21 例であった。血栓の部位 は warfarin 群で中枢型 32 例、未梢型 21 例、DOAC 群で中枢型 31 例、未梢型 30 例であった。内服終了までを追跡期間とし平均 追跡期間は warfarin 群で 288.6 日、DOAC 群 278.4 日 ( $\mathrm{p}=0.57)$ で、多くは担癌状態が続いていた。内服中に血栓が再発または増 悪したものは warfarin 群 4 例、DOAC 群 0 例 $(\mathrm{p}=0.063)$ 、出血 合併症は warfarin 群 6 例、DOAC 群 7 例 $(\mathrm{p}=0.94)$ であった。両 者とも内服中に血栓症関連死はなかった。

【結語】DOAC の使用結果は warfarin と比べ再発抑制、出血合併 症予防の点から遜色ないものと考えられた。また warfarin 投与 患者の 4 分の 1 で TTR が低く、コントロールの難しさを表して いると考える。

Key words : cancer associated thrombosis, direct oral anticoagulants 


\section{PD-4-6 悪性腫瘍を併存した肺血栓塞栓症に対す る治療戦略}

市立函館病院 心臓血管外科

○森下 清文

【目的】悪性腫瘍を併存した肺血栓塞栓症(CAPE)に対する治療 戦略を、自験例を基に組み立てた。

【方法】過去 7 年間に経験した CAPE 連続 65 例を対象とした。 年歯令は $71 \pm 12$ 歳で、男性 37 例。癌腫は膵臓癌、肺癌が各 9 例 で、ついで胃癌、胆管癌が各 6 例であった。PE 発症後、半年以 内に癌死した症例は 17 例(26\%)であった。PEの重症度は collapse 4 例、massive 1 例、sub-massive 8 例、non-massive52 例 であった。薬物治療はへパリン単独が 14 例、DOAC 21 例(うちへ パリン先行使用 15 例)、ワーファリン $(\mathrm{WF}) 23$ 例(うちへパリン先 行使用 18 例)であった。併用治療として PCPS1 例、 IVC filter7 例を用いた。また遠隔期にWF から DOACへ処方を変更した症 例が 8 例あった。平均追跡期間は 16 カ月。

【成績】在院死亡は 17 例(26\%)であった。死因は癌死が 12 例 (18\%)、PE が 3 例(5\%)であった。Sub-massive の 1 例は初回歩行 時に再発死亡した。合併症としては血栓症は DOAC 処方例(変更 例も含む)で 3 例(10\%)、WF 処方例で 6 例(26\%)、また出血合併症 は DOAC 処方例(変更例も含む)で 4 例(14\%)、WF 処方例で 7 例 (30\%)であった。WF 処方例の出血合併 3 例は緊急入院を必要と した。IVC filter を用いた症例のうち 2 例は腫瘍病変からの出血 がすでにあるため filter のみで対応した。また薬物療法を工夫し たにもかかわらず血栓塞栓症を繰り返した症例も filter のみの 対応に変更した。Filter 全症例のうち 1 例が晚期に両下肢浮腫 を経験した。

【結論】血栓症ならびに出血合併症の頻度から経口の凝固薬とし てはDOAC を第一選択とすべきである。また出血合併症例、す でに腫瘍病変から出血を起こしている症例、薬物治療で血栓塞 栓症の制御不能例では IVC filter だけの対応が可能であった。

Key words : malignacy, pulmonary embolism

\section{パネルディスカッション 5}

\section{破裂性大動脈瘤に対する治療戦略}

座長：古森 公浩 (名古屋大学 血管外科)

東信良（旭川医科大学 血管外科）

\section{PD-5-1腹部大動脈瘤破裂に対する手術成績の検} 討 ; EVAR 時代における人工血管置換術の位置づけ 埼玉医科大学国際医療センター 心臓血管外科 $\bigcirc$ 栃井 将人、朝倉 利久、徳永 千穂、林 潤、 高澤 晃利、山下 健太郎、昼八 史也、堀 優人、

井口 篤志、中嶋 博之、吉武 明弘

【目的】腹部大動脈瘤破裂（RAAA）に対してはEVAR か開腹に よる人工血管置換術 $(\mathrm{GR})$ を行うか議論のあるところである. 傍 腎動脈型や慢性解離など, 解剖学的にEVAR 困難な症例もあ る. また血行動態が不安定でデバイスの準備が間に合わない場 合もある.このため当院では緊急の破裂症例は GR を第一選択 としており，その成績と妥当性を検討する.
【方法】 2008 年 1 月から 2019 年 3 月までに当院で手術した RAAA は 92 例で, EVAR 2 例を除外した GR 90 例に関して検 討.

【結果】年齢 $72.6 \pm 11.2$ 歳, 男性 78 例(86.7\%). 動脈瘤径 $72 \pm 18 \mathrm{~mm}$. ショック 35 例で心肺蘇生を 7 例に行った. 手術時間 は $325 \pm 113$ (125-702)分. 入院期間は $27 \pm 20$ (0-90)日. 30 日死 亡 8 例 (8.9\%), 病院死亡は 12 例 (13.3\%) で死因は腸管壊死 8 , LOS2, 肝不全 1 , 敗血症 1 例. 腸管壊死は 12 例に発生し 8 例が 院内死亡, 残りの 4 例のうち 2 例は転院先で死亡し, 12 例中 10 例死亡となった. 観察期間 $30.8 \pm 35.2$ か月で遠隔死亡は 13 例. 1,5 年生存率は $73.7,62.8 \%$ であった. ショックによる腸管壊死 予防，救命率向上のため，2015 年以降はハイブリッド手術室で 行い，積極的に大腿動脈から Occlusion Balloon を挿入. 血行動 態を安定させてから開腹することで救命率が向上し 2014 年ま での 57 例と 2015 年以降の 33 例では死亡率は $15.8 \%$ 対 $9.1 \%$ ( $\mathrm{p}=0.5240)$ と改善傾向にある.

【結語】当院では EVAR 時代においても循環動態が不安定な症 例の第一選択は Occlusion Balloon 使用下の GR と考えている. 血行動態が破綻する前に治療することで合併症を減らし, 救命 率を上げることが可能でショックを伴う破裂症例でも手術死亡 率は $9.1 \%$ ま改善した.

Key words : abdominal aortic aneurysm, rupture

\section{PD-5-2 破裂性腹部大動脈瘤(RAAA)に対する当} 科の EVAR 治療戦略の有益性 -治療戦略確立後の連続 EVAR の治療成績-

山口大学 器官病態外科学 血管外科 ○森景 則保、溝口 高弘、永瀬 隆、佐村 誠、 原田 剛佑、未廣 晃太郎、濱野 公一

破裂性腹部大動脈瘤(RAAA)の救命は(1)早急な proximal aortic control，(2)術後持続出血の回避、(3)Abdominal compartment syndrome の回避が必須である。2011 年より RAAAにEVARを 導入し、それらに対策を講じた 2012 年 10 月以降は全例に EVAR を施行した。当科の治療戦略を供覧し、EVAR 連続症例 の治療成績を検証した。

【対象と方法】 AI 䛦断を除外した RAAA は 43 例で、術前ショッ ク 44\%、Fitzgerald III 以上 $72 \%$ あった。瘤径 $7.7 \pm 1.8 \mathrm{~cm}$ 、

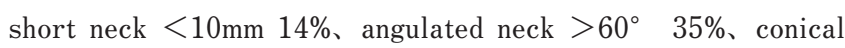
neck $21 \%$ であり、中枢ネック IFU 外は $56 \%$ であった。治療戦略 は、(1)術前業務を分担して速やかに搬入し、局麻下の大腿動脈穿 刺でバルーンを挿入して EVAR を開始し、(2) Iaエンドリーク (EL) の回避は hostile neckへの reverse slider technique や chimney 法を用い、II, IV EL に続発する出血回避は Fitzgerald

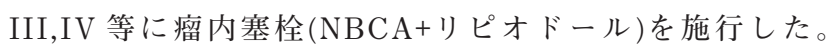
(3)EVAR 後に腹腔内圧 $20 \mathrm{mmHg}$ 以上は持続陰圧吸引療法によ る open abdominal treatment (OAT)を施行した。

【結果】術前死亡は 1 例で、手術完遂率は $98 \%$ でった。来院か ら手術まで $50 \pm 47$ 分、来院からグラフト完成まで $120 \pm 53$ 分であった。10\%に chimney EVAR、38\%に瘤内塞栓、17\%に OAT を施行した。Ia EL 0\%、II EL 9.5\%であった。術後合併症 は呼吸不全 $12 \%$ 、腸管壊死 $7 \%$ 、腎不全 $5 \%$ 、LOS、心筋梗塞、下 
肢虚血、対麻痺が各々 $2 \%$ あった。在院死亡 $9.5 \%$ 、術前死亡を

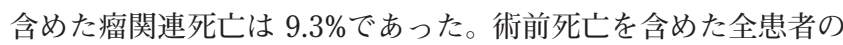
$67 \%$ 直接自宅退院し得た。

【結語】RAAA 救命のための必須事項に沿って治療戦略を確立 し、EVAR で質の高い救命が得られることが示された。

Key words: RAAA, EVAR

PD-5-3＼cjkstart破裂性腹部大動脈瘤に対するモバイル端 末ネットワークの有用性 : 単施設前向きヒストリカル コントロール研究での検証

${ }^{1}$ 東京慈恵会医科大学附属柏病院 外科 - 血管外科、 ${ }^{2}$ 東京慈 恵会医科大学附属柏病院 外科、 ${ }^{3}$ 東京慈恵会医科大学外科 学講座血管外科分野

○福島 宗一郎 1、戸谷 直樹 1、伊藤 栄作 1、

西江 亮祐 1 、三澤 健之 2 、大木 隆生 ${ }^{3}$

【背景】破裂性腹部大動脈瘤(RAAA)では, 診断から治療開始まで の時間短縮が救命に直結する。我々はモバイル端末型アプリ Join による院内 RAAA ネットワークを形成し，CT 動画を含む 患者情報と院内各部署の手術準備状況をリアルタイムに共有す ることで，緊急手術開始までに要する時間短縮を図る試みを行 つている。自施設での前向きヒストリカルコントロール研究の 成績を報告する。

【方法】 2019 年 3 月までに当院で緊急腹部ステントグラフト内 挿術(EVAR)を行った Fitzgerald 分類 2,3 の RAAAを対象と し, 2018 年 1 月の Join 導入前を $\mathrm{S}$ 群, 導入後を $\mathrm{J}$ 群とした。主 要評価項目は来院-手術開始までの時間(A-E time), CT-手術開 始までの時間(CT-E time), 副次評価項目は周術期死亡, 主要合 併症, 生存例の術後在院日数, とした。学内倫理委員会の承認取 得後に, 前向きに収集した $\mathrm{J}$ 群のデータを, ヒストリカルコント ロールとして収集した S 群のデータと比較することでJoinの 有用性を検証した。

【結果】対象 RAAA は 17 例( $\mathrm{S}$ 群: 11 例, J 群:6 例)で，平均年齢 はそれぞれ 75.5 歳, 80.0 歳, 平均大動脈瘤径は $68.7 \mathrm{~mm}, 71.8 \mathrm{~mm}$ であった。Fitzgerald 分類は S 群 2:2 例(18.2\%), 3:9 例(81.8\%), $\mathrm{J}$ 群 2:2 例(33.3\%), 3:4 例(66.7\%)で，両群の病態背景に有意差を 認めなかった。S 群, J 群の A-E time はそれぞれ 138.1 分, 94.3 分 $(\mathrm{p}=0.025), \mathrm{CT}-\mathrm{E}$ time は93.4 分, 61.2 分 $(\mathrm{p}=0.043)$ で, いずれ も J 群で有意に短かった。一方, $\mathrm{S}$ 群, $\mathrm{J}$ 群の周術期死亡は 2 例, 2 例( $\mathrm{p}=0.55)$, 主要合併症 6 例, 4 例( $\mathrm{p}=0.65)$, 生存例の術後平均在 院日数は 51.1 日, 47.7 日 $(\mathrm{p}=0.87)$ と, いずれも両群間に有意差を 認めなかった。

【結語】Join の活用により, RAAA に対する緊急手術開始までの 時間短縮が得られた。今後 RAAA 救命率向上を目指す更なる取 組みが望まれる。

Key words : Ruptured aortic aneurysm, Mobile communication application

\section{PD-5-4 下行大動脈瘤破裂に対する胸部ステント グラフト内挿術の早期および遠隔成績}

1 神戸大学 心藏血管外科、 2 神戸大学 放射線科

○中井 秀和 1 、殿城 秀人 1 、孟 順 ${ }^{1}$ 井上 大志 ${ }^{1}$ 、
陽川 孝樹 1 、邊見 宗一郎 1 、後竹 康子 1 、山中 勝弘 1 、 大村 篤史 1 、井上 武 1 、山口 雅人 2 、杉本 幸司 ${ }^{2}$ 、 岡田 健次 ${ }^{1}$

【背景】下行大動脈瘤破裂（rDTAA）に対する胸部ステントグラ フト内挿術（TEVAR）は、早期成績は良好であるが、遠隔期成 績は不明である。当院での rDTA に対する TEVAR の治療成績 を後方視的に検討した。

【対象】 2008 年 6 月から 2018 年 12 月までの期間で、rDTAAに 対する TEVAR 施行は 40 例で、これらを対象とした。

【結果】使用機種は、TAG/cTAG が 36 例、Valiant が 2 例、2 機 種 (cTAG および TX2) が 2 例であった。平均年齢 78.1 18.0 男 性 26 名 $(65 \%)$ であった。胸部大動脈瘤術後 5 例、腹部大動脈 瘤術後 5 例であった。大動脈瘤血管径は $60.6 \pm 12.6 \mathrm{~mm}$ であっ た。紡鍾状瘤は 23 例、囊状瘤は 6 例、感染瘤（疑い含む）は 5 例、仮性瘤は 4 例、急性大動脈解離 $\mathrm{B}$ 型の破裂は 2 例であった。 遠位弓部大動脈におよぶ下行大動脈瘤にはZ Zone2 landing を行 った。Landing はそれぞれZone 2 は 6 例、Zone 3 は 17 例、 Zone4 は 17 例であった。30 日死亡 3 例、病院死亡は 1 例であっ た。手術死亡 3 例を除くと TEVAR 初期成功率は $97.3 \%$ でっ た。術後合併症は、脳梗塞 5 例、paraplegia 1 例、paraparesis 1 例、大動脈瘤感染 2 例であった。遠隔期大動脈関連イベントは Type1 endoleak は 5 例 (16\%) あり、再 TEVAR が 4 例、コイル 塞栓術 1 例であった。大動脈瘤感染による Open conversion 2 例 と、残存瘤破裂が 1 例であり、大動脈関連イベント回避率は 5 年 で $64.9 \%$ であった。また生存率は 5 年 $25 \%$ と不良であった。 【結語】 30 日死亡は 3 例 (7.5\%) と良好な結果であったが、再介 入率は 8 例 $16 \%$ と不良であり改善すべき余地があった。文献的 考察を含め報告する。

Key words : Thoracic Aortic Aneurysm, Rupture

\section{PD-5-5＼cjkstart破裂性腹部大動脈瘤の治療成績}

和歌山県立医科大学 外科学第 1 講座

○湯崎 充、本田 賢太朗、金子 政弘、藤本 貴大、

上松 耕太、長嶋 光樹、西村 好晴

【背景】破裂性腹部大動脈瘤はまだまだ致命的な疾患である。治 療法についても、EVAR での良好な報告がなされる一方で、大規 模 RCT では open surgeryに対する優位性は証明されていな い。当院では、open surgery firstとして治療を行ってきた。

【目的】過去 10 年間に当院で治療を行った破裂性腹部大動脈瘤 の治療成績について検討する。

【基本方針】基本的に速やかに open surgery を行う。循環血液量 維持のため、非洗浄式自家血回収装置を用いて、置換範囲を最小 限に人工血管置換を行う。ACS 予防のためにOAM (open abdominal management）を積極的に行っている。

【対象】治療を行った破裂性腹部大動脈瘤は 58 例。うち超高齢で 開腹手術を希望されなかった 2 例と SAH 合併の 1 例に EVAR を行った。open surgery で治療を行った 55 例について検討し た。平均年齢は74.6 歳（59-90）で男女比は $47: 8$ であった。 【結果】術中止血困難の 3 例と、多臟器不全 3 例の 6 例を在院中 に失ったため、救命率は $89.1 \%$ であった。術前 Rutherford 分類と Fitzgerald 分類がともに 3 以上の重症症例が 32 例 (58.2\%)であ 
り、在院死亡はすべて重症群であった。OAM を 32 例 (58.2\%)に 行い、平均 3.6 日で 2 期的閉腹を行った。平均 ICU 滞在日数は 7.7 日で、平均在院日数は 34.9 日であった。 44 例が経口摂取可 能となり、23 例が自宅退院可能となった。遠隔生存率は 3 年 $73.1 \% 、 5$ 年 $59.1 \%$ であった。7 例が残存瘤、もしくは吻合部瘤 に対して中期、遠隔期にEVAR を行った。

【結論】Open surgery first、積極的 OAM とする当院での破裂性 腹部大動脈瘤の手術成績は良好なものであった。術前状態の悪 い症例をいかに救命するかが今後の課題である。

Key words : Rupture, AAA

\section{PD-5-6 当科における破裂性腹部大動脈瘤に対す る治療戦略}

東京医科歯科大学 血管外科

○工藤 敏文、葛井 総太郎、西澤 真人、猪狩 公宏

【目的】当科で経験した破裂性腹部大動脈瘤に対する、緊急手術 について検討する.

【症例と結果】 2011 年 8 月から 2019 年 4 月で腹部大動脈・腸骨 動脈瘤破裂症例に対する手術 23 例を経験し, 内 eEVAR 14 例, 開腹手術 9 例であった. 平均年齢は 71.1 歳で, 男性 20 例, 女性 3 例であった。破裂部位は EVAR 群では腹部大動脈瘤 (AAA) 10 例, 総腸骨動脈瘤 3 例, 内腸骨動脈瘤 1 例で、開腹群では全例 AAA であった。瘤の形態は EVAR 群で、IFU 内 12 例, IFU 外 2 例 (両側内腸骨動脈瘤症例扎よび遺残坐骨動脈併存例) であっ た。開腹群では、中枢遮断部位は 2 例が腎動脈下大動脈であり、 他の症例は腎動脈上遮断であった。両群ともに全例全身麻酔を 施行した. EVAR 群での使用デバイスは EXCLUDER 11 例, EPL 3 例で， 3 例で内腸骨動脈コイル塞栓（1例は両側）を同時 施行した。平均出血量、平均手術時間、平均 ICU 滞在期間は EVAR 群で $497 \mathrm{ml} 、 2$ 時間 24 分、6.3 日、開腹群で $3,650 \mathrm{ml} 、 3$ 時間 31 分、17 日であった. 両群ともに 30 日以内の死亡は認め なかったが，ショック状態で緊急 EVAR を行った 1 例は腹部コ ンパートメント症候群に対し開腹状態で集中管理を行ったが広 範な結腸・直腸壊死および DICで失った. EVAR 群では、上記 症例以外全例造影 CT でエンドリーク認めず現在外来通院中で ある.

【結語】当科における腹部大動脈・腸骨動脈瘤破裂症例に対する 開腹手術並びに eEVAR の成績を検討した，循環動態が比較的 安定しており, かつ動脈瘤の形態が適している症例であれば, 破 裂症例に対する eEVAR は安全かつ効果的に施行可能であるこ とが示唆された。

Key words : ruptured AAA, EVAR

\section{パネルディスカッション 6}

\section{血管内治療による下肢静脈瘤に対する治療戦略}

座長：小川 智弘 (福島第一病院 心臓血管外科)

佐戸川弘之（福島県立医科大学 心臟血管外科）

\section{PD-6-1 Short segment の直線病変に対するレ} ーザースリムファイバーの有用性

松阪打扎たクリニック

○草川均

【はじめに】定型的な伏在静脈病変の血管内焼灼術は確立された 一方で、非定型的な short segment $(\mathrm{SS})$ の直線病変に対する治療 は今まで不完全な硬化療法か外科手術で対処するしかなかっ た。最近使用可能となったレーザースリムファイバー(LSF)は径 が細く、シースの留置が不要で、SS の直線病変への応用が可能 となったので、一部症例を提示する。

【症例と方法】今回 $(\mathrm{LSF})$ を用いた $\mathrm{SS}$ 病変は、 1 不全穿通枝 (IPV)、2 再発性病変(REVAS)、3 伏在静脈高位分枝瘤形成例、4 副伏在静脈病変、 5 複雑で非定型的な逆流様式のうち、単独もし くは複数該当例である。いずれも stab avulsion での処理が困難 な深さの病変である。

【結果】症例 1-病変 $1 、 2$ の 46 歳男性で、血栓後症候群に下腿 潰瘍を併発していた。内視鏡下切離(SEPS)が癒着で不可能で、そ の後 2 回のエコーガイド下硬化療法でも 2 本の IPV は閉塞せ ず、LSF を用いて焼灼を行い、IPV は閉鎖、続いて潰瘍も治癒 に至った。症例 2-病変 2 の心房細動でワーファリン服用中の 70 歳女性で、20 年以上前に右 GSV ストリッピングを施行され、 遺残した SFJ 断端経由の REVAS に対し、LSF を用いて SFJ 断端の焼灼を行った。症例 3-病変 2、4 の 68 歳女性で、6 年前 に右 GSV ストリッピングを施行され、SFJ 断端の新生血管を介 する外側副伏在静脈(LASV)逆流に対して LSF を用いて焼灼を 行った。症例 4一病変 $1 、 5$ の 76 歳女性で、下腿下部内側皮膚病 変を伴う下腿 GSV 逆流と不全穿通枝に対して LSF 用いて 焼灼を行った。

【まとめ】非定型的な SS の直線病変に対して、レーザースリム ファイバーはより低侵襲かつより確実な血流遮断が可能で、有 用な治療選択肢となりうる。

Key words : endovascular venous ablation, slim fiber

\section{PD-6-2ＩPVに対する新たな選択肢である PAPS の術式紹介と治療成績}

1 仁鷹会 たかの橋中央病院 血管外科、 ${ }^{2}$ 三菱三原病院 外 科

$\bigcirc$ 春田 直樹 1 、新原 亮 2 、赤羽 慎太郎 1 、築家 恵美 1

【はじめに】下腿脂肪硬化性皮膚炎 (C4b) p下腿難治性潰瘍 (C6) 病変皮下の不全穿通枝 (IPV; incompetent perforating vein)を血. 管内焼灼術を用いて遮断する術式として考案されたのが PAPs (percutaneous ablation of perforators) である。今回我々が行っ ている PAPs 術式紹介と治療成績について報告する。

【対象と方法】 2012 年 11 月より 2019 年 5 月までにPAPs を行 った男性 17 例女性 20 例の 39 肢で、年齢は $31 \sim 82$ 歳平均 
$61.3 \pm 15.3$ 歳で、Clinical 分類では $\mathrm{C} 2 ; 3$ 肢、 $\mathrm{C} 4 \mathrm{aC} 4 \mathrm{~b} ; 23$ 肢、 C5C6;13 肢であった。麻酔法は静脈麻酔もしくは腰椎麻酔で行 つた。使用機器は ELVeS1470, EndothermeLaser1470で、2018 年以降は細径ファイバーを用い、出力： 6.5 10Watt、焼灼長 : $1 \sim 8 \mathrm{~cm}$, 平均 $2.1 \pm 1 . \mathrm{cm}$ であった。

【結果】基本的に Transluminal な焼灼術を選択し、IPV一力所当 たりの LEED は $45.0 \sim 147.9 \mathrm{~J} / \mathrm{cm}$, 平均 $68.7 \pm 18.2 \mathrm{~J} / \mathrm{cm}$ で。全 例で IPV の術中閉塞が得られた。

【考察と結語】細径レーザーファイバーを用いた Transluminal 焼 灼術では、LEED； 68.9J/cm で十分な IPV 閉塞が得られた。現 状では PAPs は保険適応となっていないが、IPV 処理の有用な 選択肢であり、EVLAの穿通枝静脈への適応拡大が待たれる。

Key words : stasis dermatitis, perforating vein

\section{PD-6-3 血管内治療 硬化療法の存在価値}

いわた血管外科クリニック

○岩田 博英

【目的】静脈瘤に対しての血管内治療は、下肢静脈瘤血管内焼灼 術と硬化療法の 2 本立ての時代である。硬化療法の適応となる 人も多いが、手技の煩雑さ、診療報酬の低さ、合併症の多さから 硬化療法は行わない施設も多い。硬化治療の合併症を検討し問 題点を明らかにした。

【対象】開院 2013 年 10 月から 5 年間に施行した治療数は 6662 肢であり、そのうちの硬化療法を施行した 1355 肢(20\%)を対象 とした。

【方法】硬化療法はフォーム硬化療法あるいは液体硬化療法で、 薬液はポリドカスクレロール $(0.5 \%$ あるいは $1 \%)$ を用いて施行 した。硬化療法前後で皮膚弾力度と色素沈着の度合いをメラニ ン測定装置を用いて測定した。

【結果】 1 年目は総治療肢数 1130 肢、硬化療法 108 肢(9\%)。2 年 目は 1436 肢中 219 肢( $15 \%) 。 3$ 年目は 1533 肢中硬化療法 333 肢 $(22 \%) 。 4$ 年目は 1198 中 270 肢 $(23 \%)$ 。 5 年目は 1365 肢中 425 肢 (31\%)と硬化療法の割合が増えていた。男女比は男 108 例、女 1247 例、平均年齢 57.4 歳。内訳は C1 867 肢、C2 447 肢、C3 9 肢、C4 13 肢、C6 27 肢であった。合併症は潰瘍 1 肢、一過性 脳虚血発作 4 肢、静脈炎 1 肢であった。硬化療法を施行し硬度計 およびメラニン測定装置で追跡可能であった 97 肢で高度な色素 沈着 3 肢、皮膚硬結 1 肢を認めた。皮膚弾力度、メラニンの測定 では硬化療法後 3 か月には硬化療法前と同じ状態に戻っていた。 【結語】年々 C1に対する硬化療法やレーザー照射の治療割合が 増えている。ほとんどの症例は硬化療法 3 か月後には硬結も色 素沈着も認められなかった。しかし硬化療法の色素沈着などの 合併症を少なくするため、低濃度から、両側の場合は軽度の肢か ら治療を行うべきと考えられた。

Key words : scleritherapy, varicose veins

\section{PD-6-4 大腿部不全穿通枝を逆流源とする大伏在 静脈瘤に対する血管内焼灼術の検討 \\ 打茶の水血管外科クリニック \\ ○伴 祐子、栗原 伸久、広川 雅之 \\ 【はじめに】典型的な大伏在静脈瘤は SFJ 逆流源としている}

が、大腿部の不全穿通枝 (IPV)、いわゆる Dodd 穿通枝不全を主 な逆流源とする大伏在静脈瘤も少なからず存在する。以前は大 腿部 IPV を結紮切離してストリッピング手術が行われていた が、血管内焼灼術(ETA)では IPV を結紮せず大伏在静脈 (GSV) 本幹のみを焼灼するか、IPV 内にカテーテルを誘導して IPV か ら GSV を焼灼する。今回われわれは、大腿部 IPV に起因する大 伏在静脈瘤に対して GSV 本幹のみに ETA を施行した症例を 検討したので報告する。

【対象】 2011 年 1 月より 2017 年 3 月までに当院で ETA を施行 した 13201 肢のうち、大腿部の IPV が主な逆流源となっていた 大伏在静脈瘤症例 166 例 166 肢 (1.3\%、男 : 女 $=57: 109$ 、平均年 齢 63 歳、CEAP 分類 2:3:4-6=113:12:41）を対象とした。

【方法】ETA は血管内レーザー焼灼術打よび高周波焼灼術を施 行、手術は穿刺アプローチにて光ファイバー（カテーテル）を GSV 遠位部から大腿部 IPV を越えて SFJ 近傍まで挿入、TLA 麻酔下に静脈を焼灼した。超音波検査による術後経過観察を行 い、静脈閉塞および再発の有無を検索した。

【結果】GSV およびIPVの平均径はそれぞれ $6.0 \pm 1.3 \mathrm{~mm}$ 、 $5.2 \pm 2.0 \mathrm{~mm}$ 、IPV の中枢側 GSV が正常であったのが 76 肢、弁 不全を認めたのが 27 肢、高位結紮術後が 6 肢であった。術後合 併症として IPV にEHIT の Class 2 に相当する血栓が認められ たのが 1 肢、Class 3 相当が 1 肢で、全例抗凝固療法を施行した。 平均観察期間は 9.3 ヶ月で、大腿部の IPV による再発は 6 肢 (3.6\%) に認められた。

【まとめ】大腿部 IPV を主な逆流源とする大伏在静脈瘤に対する ETA は、IPVの結紮や焼灼を行わなくても再発は少なく、治療 成績も良好であった。

Key words : ETA, Dodd IPV

\section{PD-6-5 下肢静脈瘤血管内焼灼術の中期治療成績 と血栓性合併症の検討}

1 川崎医科大学 心臓血管外科、2 川崎医科大学 生理学 1 $\bigcirc$ 田淵 篤 1 、柚木 靖弘 1 、渡部 芳子 2、桑田 憲明 1 、 田村 太志 ${ }^{1}$ 、山澤 隆彦 1 、古川 博史 ${ }^{1}$ 、金岡 祐司 ${ }^{1}$ 、 種本 和雄 1

【目的】下肢静脈瘤血管内焼灼術の中期治療成績および血栓性合 併症（EHIT、DVT）の臨床像、治療、転帰を検討する。

【対象、方法】 2011 年 10 月から 2018 年 5 月に当科で $980 \mathrm{~nm}$ ダ イオードレーザーを用い血管内焼灼術を行った伏在型静脈瘤 1172 肢を対象とした。術後経過観察は術翌日、7-10日、1、6、 12、24 力月で行い、治療血管閉塞率、Venous Clinical Severity Score (VCSS)を検討した。超音波検査で治療血管閉塞、EHIT、 DVT の有無を検討し、静脈機能は空気容積脈波法で Venous Filling Index (VFI)、Venous Volume (VV)を測定し、術前值と比 較検討した。

【結果】治療血管累積閉塞率は術後 12 力月 $98.2 \%$ 、24 力月 $97.9 \%$ であった。VCSS は術前 $5.2 \pm 2.3$ 、術後 12 力月 $0.6 \pm 1.0$ 、 24 力月 $0.6 \pm 1.0$ で有意に改善した。VFI, VVの術前值は $6.3 \pm 4.3 、 144.9 \pm 63.9$ 、術後 12 力月值は $2.4 \pm 1.8 、 117.9 \pm 51.1$ 、 24 力月は $2.6 \pm 1.8 、 121.4 \pm 49.1$ で有意に改善した。EHIT class3 は 1.1\%（13 肢）に生じ、診断時期は術翌日 $30 \%$ 、術後 7-10日 
$70 \%$ あった。治療はへパリン+ワーファリン 4 例、ヘパリン +DOAC2 例、DOAC 単剂 7 例に行い、各々 1-6 カ月、 $1-3$ 週間、 $1-2$ 週間で全例軽快した。DVT は $0.69 \%$ (8 肢) に生じ、診断 時期は術翌日から 12 力 月と様々で、部位は大腿静脈 2 肢、膝墖 静脈 1 肢、ヒラメ静脈 5 肢であった。治療は大腿、膝窩静脈血栓 症の 3 肢にDOAC 単剂で行い、 2 週間一 1 力月で軽快した。肺塞 栓症をきたした症例はない。

【結語】1.血管内焼灼術の治療成績は良好であり、標準術式として 問題はないと考える。2.血管内焼灼術後の血栓性合併症に対し、 DOAC は血栓消失が早く、有用であった。

Key words : EVLA, EHIT

\section{PD-6-6 当院における血管内焼灼術の治療成績 - 再発から学び、更なる治療成績の向上へ-}

西の京病院 血管外科

$\bigcirc$ 今井 崇裕

【はじめに】現在国内において血管内焼灼術は下肢静脈瘤の標準 術式になった. 当院で施行した血管内焼灼術の短期および中期 成績を検討した。

【目的】下肢静脈瘤治療は遠隔成績に課題があり, 治療成績を検 討することで, 今後の治療戦略へ反映させることを目的とした.

【対象】 2013 年 1 月-2018 年 12 月. 血管内焼灼術を施行した 4,779 例(M:1,606/ F:3,173, 64.8 12.8 歳). GSV:3,619/ SSV:1,160 例. Laser980nm:480/ Laser 1470 nm: 2,314 / Closure FAST:1,985 例.

【方法】観察期間は術後 12 力月, 超音波で評価した. 再発の定義 は, 開存または閉塞断端が深部静脈合流部から $50 \mathrm{~mm}$ 超過例と した. 検討項目は以下である. SFJ/ SPJ からの閉塞断端(mm), 合流部の分枝血流, 焼灼血管の消退率[術後径/術前径 x100](\%). 再発例は術前の MR venography を参考に, 経時的変化をビジュ アル化して評価した.

【結果】再発は 37 例(M:8/F:29, $71.2 \pm 10.2$ 歳), 全体の 0.77\%で あった.内訳は GSV:19/ SSV:18 例, Laser1470nm:13/ Closure FAST: 24 例. 早期では開存 3 例/ $50 \mathrm{~mm}$ 以上で閉塞 8 例. 中期 では $50 \mathrm{~mm}$ 以上で閉塞 25 例. 閉塞断端の新生血管 1 例. 消退率 は早期 33.4/ 中期 41.6\%. 血流のある分枝は早期 0.53/ 中期 1.14 本.

【考察】早期再発は GSV 例が多く, 中期再発は SSV 例が多かっ た. GSVでは焼灼血管が長く的確な焼灼手技が不可欠であり， SSV は平均 91.5 日で再発していることから, 慢性的な膝関節 の屈伸や腓腹部の筋ポンプ作用などが血流再開に影響している ではないか.

【結語】再発例は早期と中期に分けて考える必要があり, 術前に 治療血管を適切に評価することで, さらに治療成績が向上する と思われた。

Key words : Varicose Veins, Endovenous Ablation

\section{PD-6-7 下肢静脈瘤ラジオ波治療後 EHIT 予防に おける浅腹壁静脈血流の意義 \\ 赤穂中央病院 心臓血管外科}

○北川 敦士、山田 幸夫、長尾 俊彦
【目的】下肢静脈瘤ラジオ波治療 (RFA) 後の EHIT について, 浅 腹壁静脈 (SEV)の点から検討した.

【対象と方法】 2014 年から 2018 年の間に RFA を施行した GSV 静脈瘤 239 肢中, 術後血管エコーで SEV を含め評価した 125 肢 (平均年齢 67 歳, 女性 80 肢) を対象とした. CEAP 分類上, C2: 62 肢, C3: 38 肢, C4 以上: 25 肢であった. EHIT1 以上群を EHIT+群, EHIT なしを EHIT- 群とした. SEV と SFJ 間の距 離を SEVD と定義し, 何 $\mathrm{mm}$ 未満 (1 10mm 未満)で最も EHIT を発症しうるかを $1 \mathrm{~mm}$ 毎に検討, short SEVD (s SEVD)と 定 義した. EHIT 危険因子は，75歳以上，女性， CEAPC3 以上 (CEAP $>C 3)$, 静脈追加手術, 静脈瘤手術既往, GSV 血管径 $7.5 \mathrm{~mm}$ 以上 (GSV>7.5), s SEVD とした. 検討項目は, EHIT 発 症率, SEVD 值 (EHIT+群 vs -群), s SEVD の決定, および EHIT 危険因子とした.

【結果】E-HIT+群 32 肢 $(26 \%)$, EHIT-群 93 肢(74\%). EHIT 内 訳は EHIT 1: 24 肢, EHIT 2: 5 肢, EHIT3: 3 肢, EHIT4: 0 肢で あった.SEVDは, EHIT+群: $5.2 \pm 3.9 \mathrm{~mm}$, EHIT-群: $6.8 \pm 3.7 \mathrm{~mm}$ と EHIT+群で短かかった $(\mathrm{P}=0.05, \mathrm{t}$ 検定). $\mathrm{s} \mathrm{SEVD}$ は $4 \mathrm{~mm}$ 未満 (単変量解析, OR 2.92, P=0.001) であった. EHIT 危険因子は, カイ二乗検定で, CEAP $>$ C3 ( $\mathrm{P}=0.001), \mathrm{GSV}>7.5$ $(\mathrm{P}=0.002), \mathrm{s} \operatorname{SEVD}(\mathrm{P}=0.01)$ が有意であった. 多変量解析上, CEAP $>$ C3 (OR 3.39, 95\% CI 1.30-8.86, $\mathrm{P}=0.013$ ), GSV $>7.5$ (OR 3.31, 95\% CI 1.33-8.25,P=0.01), s SEVD (OR 2.70, 95\%CI 1.09-6.70, P=0.032)が有意であった.

【結語】 RFA 後 EHIT 危険因子として, CEAP $>C$ C, GSV $>7.5$ に加え, s SEVD が有意であった. 以上より, EHIT の予防には, 上記の危険因子を有する症例について,術後注意深い経過観察が 重要である.

Key words : varicose vein, EHIT

\section{パネルディスカッション 7}

\section{頚動脈狭窄に対する治療戦略}

座長: 金岡 祐司 (川崎医科大学 心臓血管外科)

山上宏（大阪医療センター 脳卒中内科）

\section{PD-7-1 積極的内科治療 VS 血行再建術}

国立病院機構大阪医療センター 脳卒中内科

○山上 宏

頚動脈狭窄症は、虚血性脳血管障害の主要な原因のひとつであ り、主に動脈硬化によって生じることが多い。一般的に、過去 180 日以内に同側内頝動脈領域の神経学的症状の既往を有する場合 に症候性、攵机以外は無症候性と定義される。虚血性脳血管障害 を生じる機序には、血行力学性と塞栓性がある。血行力学性機序 では、高度狭窄により脳潅流圧が低下し、血圧低下や脱水などを 契機に脳虚血症状が出現する。塞栓性機序では、プラークの破綻 により形成された血栓が、脳動脈や眼動脈に動脈原性塞栓症を 生じる。

頝動脈狭窄症に対する治療戦略は、症候性と無症候性で大きく 異なる。症候性䅡動脈狭窄では、発症早期の再発率が高いため、 軽症であっても発症 24 時間以内に抗血小板薬 2 㘊併用療法を 
開始すべきである。また、年齢や合併症などの患者背景、狭窄血 管の形態、脳血流評価などをふまえて、血行再建術の適応を検討 する。血行再建術には、頚動脈内膜剥離術 (CEA) と頚動脈ステ ント留置術 $(\mathrm{CAS})$ があるが、プラーク性状評価や解剖学的形態 を参考に治療法を選択する。

一方、無症候性䅡動脈狭窄では、まずは積極的内科治療により動 脈硬化危険因子の十分な管理を行う。降圧療法は著明な脳血流 の低下がない限り血圧 $130 / 80 \mathrm{mmHg}$ 未満を、脂質低下療法はス タチンや PCSK9 阻害薬を用いて LDL コレステロール值を $70 \mathrm{mg} / \mathrm{dL}$ 未満を目標とし、禁煙を徹底する。抗血小板薬の脳卒中 一次予防効果は明らかではないが、中等度以上の狭窄では心血 管疾患の予防目的に単剤による抗血小板療法を考慮する。その 上で、高度狭窄例や経時的に狭窄が進行する例に対しては血行 再建術を考慮する。

Key words : carotid artery stenosis, therapy

\section{PD-7-2 Monorail タイプ頸動脈ステント治療に おけるダブルワイヤー手技の有用性}

育和会記念病院 循環器内科

○河原田 修身

頝動脈ステント治療で使用されるステントが Over-the-wire タ イプの時代、遠位バルーン保護下の頸動脈ステント治療におけ るダブルワイヤー手技の有用性について報告されている (Kawarada O, et al. J Interv Cardiol 2007; 20: 55-62)。手技の 特徵として 1) Percusurge Guardwire を進める前に、まず 0.014 インチフロッピーガイドワイヤーで病変を通過させる、2)

Percusurge Guardwire を進めてから、先の 0.014 インチフロッ ピーガイドワイヤーに前拡張バルーンを追従させる、3）遠位保 護バルーン拡張後に、前拡張バルーンを拡張させ脱気とともに 0.014 インチフロッピーガイドワイヤーと前拡張バルーンを抜 去し Monorail ステントを進め展開することがあげられる。ダブ ルワイヤー法によって Percusurge Guardwire を進めやすくな ることに加え血流遮断時間の短縮が可能となる。現在では、遠位 フィルター保護デバイスの登場と同時に Monorail タイプのス テントの使用が可能となっている。遠位バルーン保護は遠位フ イルター保護よりもより確実に塞栓を予防できる利点がある反 面、血流遮断による神経症状出現が懸念されている。今回、遠位 バルーン保護による血流遮断時間を短縮するためにダブルワイ ヤー手技を用いた Monorail 頸動脈ステント治療の実際につい て報告する。

Key words : carotid artery stenting, double wire

\section{PD-7-3 頸動脈狭窄症に対する慈大式小切開 Eversion 法内膜剥離術の検討：低侵襲時代における 意義}

東京慈恵会医科大学 血管外科

○宿澤 孝太、高橋 潤次、村上 友梨、百瀬 匡亨、 大森 慎子、瀧澤 玲央、馬場 健、原 正幸、 前田 剛志、立原 啓正、大木 隆生

【目的】慈大式小切開 Eversion 法内膜剥離術(CEA)の特徴の一つ は塞栓源であるプラークのある内頸動脈の剥離操作を総頸動
脈・外頸動脈遮断後に行うことである。今回、当科で施行した慈 大式 CEA の治療成績の解析を行った。

【対象と結果】過去 12 年間で 221 例の頸動脈狭窄症の治療を行 つた。頸動脈ステント術(CAS)は CEA ハイリスク症例のみに選 択しており、内訳は CEA:172 例(77.8\%)、CAS:48 例(21.7\%)、同 側頸動脈病変に対する CEA と CAS の同時治療: 1 例(0.5\%)であ った。172 例のうち 163 例(94.8\%)に対して慈大式 CEA を施行 し、病変の主座が総頸動脈であった 9 例 $(5.2 \%)$ は従来の縦切開 CEA を施行した。慈大式 CEA では全例術中・術後造影を施行 し、その平均皮切長、手術時間、出血量はそれぞれ $32 \pm 4.8 \mathrm{~mm}$ 、 $183 \pm 56.2 \mathrm{~min} 、 182 \pm 144 \mathrm{ml}$ であった。頸動脈クランプ時間は $39 \pm 14 \mathrm{~min}$ で、頸動脈分岐部から $26 \pm 7.7 \mathrm{~mm}$ のプラークを摘出 した。術後平均在院日数は $9.9 \pm 25$ 日であり、周術期合併症は、 脳梗塞を 2 例 $(1.2 \%)$ 、過灌流症候群による脳出血を 1 例 $(0.6 \%)$ 、 頸部血腫を 1 例 $(0.6 \%)$ に認めた。術中造影で外科的到達点を超え た高位に解離を認めた 3 例に経総頸動脈的にCAS を施行した。 $52 \pm 36$ ヶ月の術後平均観察期間中に、同側脳梗塞を 1 例 $(0.6 \%)$ 、 再狭窄を 3 例 $(1.8 \%)$ に認めた。再狭窄症例 3 例のうち 2 例に対 して CAS による追加治療を行い、残る 1 例は経過観察中であ る。術後 36 ケ月の脳梗塞回避率、再狭窄回避率はそれぞれ 99.3\%、98.6\%であった。

【結語】慈大式 CEA は約 $3 \mathrm{~cm}$ の小切開で施行可能であり、極め て低い術後脳梗塞発生率を可能にしている。低侵襲時代におい ても CEA、とりわけ整容的で安全な慈大式 CEA が頸動脈狭窄 症の標準術式であり普及に努めたい。

Key words : carotid artery stenosis, carotid endarterectomy

\section{PD-7-4 無症候性頚動脈狭窄に対する CEA につ いて}

国際医療福祉大学三田病院 血管外科

○松倉 満、折口 信人、重松 邦広、小櫃 由樹生

【背景】無症候性頝動脈狭窄 $(\mathrm{ACS})$ は日常診療で遭遇し得る疾患 の一つであり、その有病率は年齢に比例し 80 歳以上で打よそ $10 \%$ 程度とされる。ACS に対する CEA は脳卒中発症リスクを 下げる予防的手術であり、手術に伴う脳神経合併症は $0 \%$ となる のが理想である。本邦で CEA 適応となる患者群はハイリスク症 例も多く含まれており、より精確で確実な手術手技の遂行が求 められる。当院で ACSにCEA を行った症例について検討した ので報告する。

【対象】 2012 年 7 月から 2019 年 3 月の期間中に ACS の診断で CEA を施行した連続 30 症例を解析対象とした。男女比は $27: 3$ で、平均年齢は $71.7 \pm 8.3$ 歳。併存疾患として高血圧 $(97 \%) 、$ 脂質 異常症(63\%)、糖尿病(57\%)を認めた。術前頸動脈 US で病変部の 平均 area stenosis $80.7 \pm 8.8 \%$ 、平均流速 $2.3 \pm 0.6 \mathrm{~m} / \mathrm{sec}$ であっ た。

【結果】CEA 術式として Eversion 25 例、静脈パッチ形成術 5 例 (4 例は術中頸動脈断端圧 $<40 \mathrm{mmHg}$ でシャント使用)が施行さ れ、頸動脈遮断時間平均は $43 \pm 10$ 分であった。術後 30 日以内の 脳卒中は 1 例(対側の小脳梗塞)であり、心筋梗塞・死亡患者は認 めなかった。退院後まで遷延した神経障害を 2 例認めた(顔面神 経麻痺 1 例、嚥下障害 1 例)が、リハビリテーション施行により 
回復した。観察期間中に他病死を 2 例認め、再狭窄症例は認めな かった。

【考察】術後合併症は対側小脳梗塞 1 例のみで‘手術リスク $3 \%$ 未 満をを満たしており、ACS に対する CEA は治療方針として妥当 と考えられた。当科で施行している手術手技を供覧する。

Key words : carotid artery stenosis, carotid endarterectomy

\section{PD-7-5 当科における内頸動脈狭窄に対する治療} 戦略 : コンピューターシミュレーションモデルを用い た脳血流予備能の検討

\section{東京大学 血管外科}

○高山 利夫、松浦 壮平、花田 和正、大片 慎也、 佐野 允哉、宮原 和洋、福原 菜摘、伊佐治 寿彦、

赤井 隆文、保科 克行

【背景】安全な血栓内膜摘除術 (CEA)のために頸動脈遮断時の 脳虚血而性評価は重要である。対側内頸動脈 (ICA) に狭窄や閉 塞病変を有する場合はシャント使用が望ましいと考元られるが 明らかな使用基準等は存在せず、個別に判断されているのが現 状である。

【目的】(1) 当科での CEA 症例を対側 ICA 病変の有無により断 端压とシャント使用状況を比較検討し選択の妥当性を評価す る。(2) 脳血流シミュレーションモデルを用いて頸動脈遮断時の クリティカルポイントを探索する。

【方法】（1）対側 ICAにNASCET 法 70\%以上の狭窄もしくは閉 塞病変を有した症例を予備能低下群 (低下群)、笛の他をコント ロール群（C 群）と設定し比較検討した。(2) 対側 ICA に狭窄 部を有する脳血流シミュレーションモデルを作成し、対側 ICA 狭窄度の変化に応じてWillis 動脈輪（CoW）血流方向の変化や 同側断端圧の変化を計算した。

【結果】(1) 過去 20 年間に患者 88 人に対し 95 例の CEA が施行 され、うち低下群 18 例、C 群 77 例だった。平均断端圧は低下群 が有意に低く $(33.3 \mathrm{mmHg}$ 対 $46.2 \mathrm{mmHg} 、 \mathrm{P}=0.006)$ 、シャント 使用率は低下群で有意に高かった ( $94 \%$ 対 $53 \% 、 P=0.0013)$ 。術 後 5 年目までの生存率と脳梗塞回避率は両群に有意差を認めな かった。（2）仮想モデルの対側 ICA 狭窄率が 50\%を越えると断 端圧が低下し始め、70\%を越えると $\mathrm{CoW}$ 内の前交通動脈動脈血 流方向が反転し、遮断時の高度予備能低下が示唆された。

【結語】対側 ICA 病変合併例は頸動脈遮断時の断端圧が有意に低 值であり、特に $70 \%$ 以上の狭窄を有する場合は高度な予備能低 下が予想され、適切なシャント使用が望ましいことがコンピュ ーターシミュレーションモデルからも襄付けられた。

Key words : Carotid endarterectomy, Cerebral perfusion simulation

\section{パネルディスカッション 8}

\section{血栓後症候群に対する治療戦略-}

座長 : 孟真 (横浜南共済病院 心臓血管外科)

八巻隆 (東京女子医科大学東医療センター 形成外科)

\section{PD-8-1 うっ滞性下腿潰瘍を伴う血栓後症候群症} 例に対する不全穿通枝の治療選択肢

松阪打打たクリニック

○草川 均

【はじめに】 2012 年から 2018 年の 7 年間に経験した 3000 肢強 の下肢静脈瘤手術の中で、6 肢(約 $0.2 \%$ )にて、血栓後症候群 (PTS)に伴う下腿潰癔症例に対し、原因と判断した不全穿通枝 (IPV)に対する治療を 9 回施行したので報告する。

【症例と方法】症例は男性 4 例 4 肢、女性 2 例 2 肢で、45-68 歳、 左/右は 5/1 肢、DVT の発症は 7-40 年前、抗凝固療法は 1 肢の みで施行されており、先天凝固異常例はなし、深部静脈病変は、 骨盤静脈通過障害については 2 肢でなし、 4 肢で不明、大腿㮏窝 動脈については逆流 4 肢(2 肢で陳旧性壁在血栓)、通過障害に逆 流が併存するもの 1 肢、閉塞 1 肢であった。これらの症例ののべ 14 本の IPV に対し行った 9 手技の内容とその成否、IPV の数 と径、潰瘍歴、潰瘍の状態、潰瘍治瘺、再発について検討した。 【結果】IPV に対する治療は、内視鏡下筋膜下切離(SEPS) 4 肢 6 本(成 3、否 3)、エコーガイド下フォーム硬化療法(UGFS)2 肢 3 本(成 0 、否 3 )、スリムファイバーレーザーカテーテル焼灼 (PAPs) 2 肢 4 本(成 3 、否 1 )、直接切離 1 肢 1 本(成)であった。IPV の数は 2 本 2 肢、 1 本 4 肢、径は $1.7-5 \mathrm{~mm}$ であったが、数と太さ に成否との因果関係は少数分析ながら認められなかった。潰瘍 については、術前潰瘍歴は 2 か月から 5 年、大きさは $1 \mathrm{~cm}$ 径 1 個から、下腿の広範囲の地図状潰瘍まであり、全肢で潰愓は治 痛、治癒までの期間は 1 か月から 8 か月で、潰瘍治痛後のフォロ ーアップは 6-78 か月で再発は現時点で 0 肢である。

【まとめ】症状の原因と考えられるIPVに対する治療としては、 皮膚病変のない部位では直接切離、皮膚病変部では、SEPS、 PAPs、UGFS の選択肢がある。それ艺れに特徴があり、これら の治療についての評価を、文献的知見を踏まえて行う。

Key words : Postthrombotic syndrome, Incompetent perforating vein

\section{PD-8-2 当院における血栓後症候群の診断、治療ス トラテジー}

1 福岡山王病院 血管外科、2 福岡山王病院 循環器科 ○星野 祐二 1 、横井 宏佳 ${ }^{2}$

血栓後症候群(Postthrombotic syndrome:PTS)は、深部静脈血栓 症慢性期に器質化血栓による静脈流出路 (腸骨静脈領域) の狭窄 /閉塞、及び大腿・胫窝静脈領域の静脈弁変形破壊による逆流に

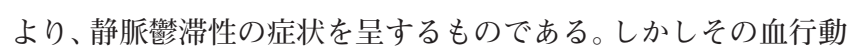
態としては深部静脈不全だけでなく表在静脈不全、穿通枝不全 の病態も合併するため、午の治療戦略としては、表在静脈手術、 穿通枝手術を含めた上で深部静脈へのインターベンションを考 慮する必要がある。しかしながら深部静脈への治療介入に関し 
ては、本邦では静脈ステントが未だ保険収載されていないため ごく限られた施設でしか行われていないのが現状である。当院 では、深部静脈系への血管内治療、また深部静脈弁形成術まで、 積極的に深部静脈への治療まで行っている。その治療指針とし ては、表在静脈不全、穿通枝不全を伴う深部静脈不全の場合は、 まずシンプルな伏在静脈処理、及び穿通枝の処理を第一選択と し、上記手技を施行してもなお難治性の病態の場合、腸骨静脈へ のカテーテルインターベンションの可能性を考慮する。上記手 技全てをもってしてもな推治性の症例に対しては、最終的に 深部静脈弁形成術まで施行するといったストラテジーとしてい る。深部静脈への治療介入は、それ単独で完結するものではな く、腹部骨盤内〜患肢における全ての静脈血行動態の把握の上 に成り立つものであり、また術後に長期抗凝固療法が必要とな るため、その適応、施行するタイミングについては、熟考の上に 決定する必要がある。今回、当院に打ける PTS に対する診断、治 療について、その適応、治療方針、及び治療成績を含め報告する。 Key words : PTS, Venous stent

\section{PD-8-3無侵襲検査法を用いた深部静脈血栓後遺 症の予測に関する興味ある知見}

東京女子医科大学東医療センター 形成外科

○巻 隆、石川 昂央、佐々木 友美子、内田 智美、 井砂 司

【目的】深部静脈血栓症（DVT）後の静脈還流障害の観点から深 部静脈血栓後遺症（PTS）の予測因子を検討した報告は少ない。 われわれは、デュプレックス超音波検査と近赤外分光装置 (NIRS) を用いてPTS の発症予測を行い、興味ある知見を得た ので報告する。

【方法】1. DVT 121 例を対象とし、発症後 6 ケ月目にデュプレッ クス超音波検査で静脈閉塞打よび逆流評価を行った。2. DVT129 例を対象とし、発症後 6 ヶ月目に下腿筋の酸化へモグ ロビン $(\mathrm{O} 2 \mathrm{Hb})$ および還元へモグロビン $(\mathrm{HHb})$ 動態を近赤外 分光装置で評価した。立位ではその増加量 $(\triangle \mathrm{O} 2 \mathrm{Hbst}$ 扎よび $\triangle$ HHbst）およびピークに至る時間（TO2Hbst および THHbst）を 測定した。10 回爪先立ち運動では、O2Hb は常に減少（ O2Hbex)、HHb は一度減少 $(\triangle \mathrm{HHbEex})$ し上昇 $(\triangle \mathrm{HHbRex})$ す るため、それぞれの量を測定した。また、立位および運動終了時 における酸素化指標もそれぞれ評価した $(\triangle H b D s t$ おび HbDex)。

【成績】1.PTSを 25 例 $(21 \%)$ に認めた。PTS では閉塞・逆流 併存症例が有意に高かった $(\mathrm{P}<0.0001)$ 。膝窩静脈の最大逆流速 度が有意に PTS 群で高かった $(\mathrm{P}=0.0008)$ 。ROC 曲線を用い、 6 ヶ月目におけるカット・オフ值を求め多変量解析を行ったと ころ、膝窩静脈における最大逆流速度 $>29.7 \mathrm{~cm} / \mathrm{s}$ が PTS 発症 の独立予測因子であった (OR 13.67、 $\mathrm{P}<0.0001) 。 2.19$ 例 $(16 \%)$ にPTS を発症した。ROC 曲線を用いた解析では、TO2Hbstミ48 が PTS 発症のリスクとして有意であった $(\mathrm{p}<0.0001)$ 。多変量 解析では TO2Hbst $\leqq 48$ (OR 50.13、CI 7.91-317.58、p<0.001) が PTS の独立予測因子という結果となった。結論】静脈還流障 害の観点から PTSの予測因子は可能である。

Key words : postthrombotic syndrome, prediction
PD-8-4 深部静脈血栓症に対する抗凝固療法によ る血栓退縮効果に関する比較検討一静脈血栓後症候群 の発症予防の観点から一

杏林大学 心臟血管外科

○細井 温、布川 雅雄、市川 洋平、笹嶋 寞史、 藤巻 圭介、泾田 博

【目的】静脈血栓後症候群 (PTS) は, 深部静脈血栓症 (DVT) 発症 後の晚期合併症として重要であり, その発症には経時的な血栓 溶解過程が関与している可能性がある. 今回われわれは, DVT に対する抗凝固療法による血栓消退の程度について，直接経口 抗凝固薬 (DOAC) とへパリン・ワルファリンによる従来療法と の比較を中心に検討したので報告する.

【対象と方法】2013-2016 年に症候性 DVTにて当科で治療を受 けた 75 例, 79 肢を対象とした. 血栓溶解の程度は超音波検查あ るいは MRI，CT を用いて，DVT 発症 1，3，6，12 力月後とそ の後 1 年毎に評価した。発症時の血栓部位により, 腸骨領域 (IL), 大腿領域 (FL), 膝墖領域 (PL), 下腿領域 (CL)の 4 領域に 分割し, 領域全長の完全閉塞を 3 点, 領域の一部の完全閉塞を 2 点, 領域全長あるいは一部の部分閉塞を 1 点, 血栓を認めない場 合を 0 点として, 1 肢每に各領域の点数を加算した值を総血栓指 数として算出し, 指数の経時的変化について検討した.

【結果】対象 79 肢に打いて血栓が認められた部位は延べ 197 領 域で，内訳は IL; 31 肢，FL; 47 肢，PL; 55 肢，CL; 64 肢であ った. 抗凝固療法としては, 従来療法が 33 例, DOAC 使用が 42 例であった. 総血栓指数の変化による血栓の残存率は, 従来療法 群では 1 力月 $61 \%, 3$ 力月 $44 \%, 6$ 力月 $37 \%, 12$ 力月 $28 \%$ であ

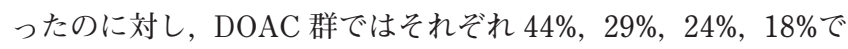
あり，1，3，6 ケ月時点で DOAC 群の方が従来療法群よりも有意 に血栓残存率が低かった。

【まとめ】DOAC は, 従来の抗凝固療法に比して治療早期の血栓 退縮勃果が高く, PTS の発症予防に寄与する可能性が示唆され た.

Key words : postthrombotic syndrome, DOAC

\section{パネルディスカッション 9}

\section{腹部内臓動脈瘤（含腎動脈瘤）に対する治療戦略}

座長: 石橋 宏之 (愛知医科大学 血管外科) 村上 卓道（神戸大学 放射線診断・IVR 科）

\section{PD-9-1当院における腎動脈瘤に対する治療方針、 成績の検討}

1 東京巨樹の会 東京品川病院 血管外科、2 石心会 川崎幸 病院 泌尿器科、3てとあしの血管クリニック東京

○光岡 明人 1 、鈴木 理仁 ${ }^{2}$ 、井上 芳徳 ${ }^{3}$

【はじめに】以前より腎動脈瘤の治療適応は妊娠時期を除いた患 者に限定すると $20 \mathrm{~mm}$ 以上の瘤が治療適応とされる。近年腎動 脈瘤は破裂する危険性が低く、30 $\mathrm{mm}$ 以上が手術適応で良いとす る議論がある。しかし発生部位は腎動脈本管に形成されること はまれであり、その第一、第二分岐にできることが多く、腎動脈 瘤が増大した場合、血管内治療にて完結できないことがある。当 
院では以前の適応通りに対応し、分枝の温存が可能な場合は血 管内治療（IVR）を第一選択とし、不可の場合に open surgery と している。当院での治療成績を提示し、若干の文献的考察を加え 報告する。

【対象と方法】 2014 年 4 月から 2019 年 4 月までに治療した腎動 脈瘤 8 症例を対象とした。IVR 群（I 群）は 5 例（紡錘瘤 1 例、 囊状瘤 4 例)、open surgery 群 (0 群) 3 例 (震状瘤 3 例) であり、 その 2 群の治療成績を比較検討した。

【結果】平均手術時間 I 群 210 分 O 群 478 分であった。動脈径 I 群 $18.8 \mathrm{~mm} \mathrm{O}$ 群 $21.7 \mathrm{~mm}$ であった。I 群の治療法はコイル塞栓 4 例 ( \pm balloon or stent assist)、コイル塞栓不能例 1 例であっ た。瘤の局在は、本幹 2 例 腎動脈第一分岐 3 例であった。合併 症は 1 例腎動脈腹側枝閉塞、 1 例に腎動脈損傷による腎被膜下血 種を認めた。O 群の治療は瘤切除十パッチ形成術 2 例、自家腎移 植 1 例であった。瘤の局在は第一分岐 2 例、第二分岐 1 例であっ た。合併症は腎動脈上極枝閉塞を 2 例認めた。 I 群、O 群ともに 術後重篤な腎機能の低下を認めなかった。

【結語】I 群、O 群ともに重篤な術後合併症を認めず、積極的な治 療介入は妥当であると考えられた。

Key words : renal aneurysm, visceral aneurysm

\section{PD-9-2 腎動脈瘤に対する治療成績}

国立循環器病研究センター 心藏血管外科

○井上陽介、松田 均、松尾二郎、四條崇之、

清家 愛幹、上原 京勲、佐々木 啓明、小林 順二郎

【背景】当院ではコイル塞栓術による梗塞が一部にとどまるもの には血管内治療を、広範囲に及ぶと予想される腎門部腎動脈瘤 には外科的手術介入を行ってきた。

【対象】 2002 年から 2019 年 4 月までに腎動脈瘤と診断された 49 例 (60土16 歳、女性 30 例、右 30 例 左 17 例 両側 2 例)を 後方視的に検討した。

【結果】経過観察中の 25 例の内、瘤径 $10 \mathrm{~mm}$ 以上の症例は 14 例 (手術待機 4 例、血管型エーラスダンロス症候群 2 例、悪性疾 患・腫瘍合併 4 例、その他 4 例)であった。治療介入した 24 例の うち外科的手術は 15 例 (56 113 歳、女性 9 例、右 9 例、左 6 例)、 コイル塞栓術は 9 例 $(53 \pm 17$ 歳、女性 8 例、右 6 例、左 3 例 $)$ であった。外科的治療の適応は瘤径 $20 \mathrm{~mm}$ 以上で、 1 例に背部痛 (23mm) を伴った。術式は、瘤縫縮 2 例、瘤切除・再建 12 例、胸 腹部置換 1 例であった。胸腹部置換以外は無輸血で終了した。 eGFR は術前 $76.6 \pm 13.5$ に対して術後 $74.4 \pm 15.9 \quad(\mathrm{p}=0.46)$ と 増悪を認めず全例で術後合併症なく独歩退院した。コイル塞栓 術の適応は瘤径 $15 \mathrm{~mm}$ 以上で、全例で極枝レベルのコイル塞栓 を行っていた。1例でコイルの移動による片腎梗塞を合併した。 eGFR は術前 $85.5 \pm 25.5$ に対して術後 $72.1 \pm 32.2(\mathrm{p}=0.02)$ と低 下を認めた。治療介入例の術後平均経過観察期間は $57 \pm 44$ ヶ月 で、死亡症例や透析導入に至った症例は認めなかった。

【結語】腎動脈瘤に対する治療介入時の年齢は 50 歳台と比較的 若年であった。㹂門部腎動脈瘤に対する外科的手術は腎機能温 存という観点で有用な選択肢の一つと考えられた。コイル塞栓 術は、腎機能は低下するものの、遠隔期に透析などの新規導入は なく、腎梗塞が限局的の予測される場合には有用な治療である
と考えられた。

Key words : renal artery aneurysm, outcome

\section{PD-9-3当院における脾動脈瘤に対する動脈塞栓 術の治療成績}

神戸大学医学部附属病院 放射線診断・IVR 科

○岡田 卓也、佐々木 康二、Hamada Mostafa、

堀之内 宏樹、元津 倫幸、上嶋 英介、祖父江 慶太郎、

山口 雅人、杉本 幸司、村上 卓道

【背景と目的】脾動脈瘤は腹部内臓動脈瘤で最も頻度が高く、動 脈塞栓術などの血管内治療が広く施行されている。良好な治療 成績が報告されているが、脾梗塞などの合併症が問題となるこ ともある。当院における脾動脈瘤に対して動脈塞栓術を行った 症例について、塞栓術の有効性や安全性について検討する。

【対象と方法】 2006 年 1 月から 2019 年 4 月までに当院で脾動脈 瘤に対して動脈塞栓術を行った 27 症例を対象とし、後方視的に 検討した。検討項目は瘤の性状、塞栓方法、技術的成功率、合併 症、再開通率とした。

【結果】平均瘤径は $27.1 \mathrm{~mm}(8 \sim 62 \mathrm{~mm})$ 。全て真性瘤であり、瘤 の部位は脾動脈本幹が 17 例、脾門部が 10 例であった。全例で塞 栓に成功し、技術的成功率は $100 \%$ あっった。塞栓方法は脾動脈 本幹では packing が 3 例、isolation が 7 例、isolation + packing が 7 例であり、脾門部では packing が 1 例、isolation が 3 例、 isolation + packing が 5 例であった。合併症は脾動脈本幹の塞栓 では脾梗塞が 3 例 $(18 \%) 、$ 膵炎が 2 例 $(12 \%)$ であり、脾門部の 塞栓では脾梗塞が 8 例 (80\%)、門脈血栓が 2 例 (20\%)であった。 1 例 $(4 \%)$ で瘤内血流の再開通を認めた。

【結語】脾動脈瘤に対する動脈塞栓術の有効性は高いが、脾動脈 本幹では膵炎、脾門部では脾梗塞に特に留意が必要である。

Key words : Splenic artery aneurysm, Embolization

\section{PD-9-4当科で経験した腹部内臟動脈瘤症例の検 討}

名古屋大学大学院 血管外科

○高橋 範子、池田 脩太、川井 陽平、鶴岡 㻟也、

榊原 昌志、飯井 克明、杉本 昌之、新美 清章、

児玉 章朗、坂野 比呂志、古森 公浩

【目的】当科で治療した腹部内臓動脈瘤に関して臨床的検討を行 い、文献的考察を加えて報告する。

【対象】 2011 年 4 月〜 2019 年 5 月に治療した腹部内臓動脈瘤症 例の患者背景、診断、治療、初期成績、遠隔期成績を後ろ向きに 検討した。

【結果】男性 16 例、女性 9 例の計 25 例で、年齢は $34 \sim 76$ 歳で あった。有症状は 5 例であり、うち 1 例は破裂、 1 例は急速拡大、 1 例は感染、 1 例は解離であった。その他 20 例は無症状で偶発的 にCT または超音波検査で診断された。瘤径は $9 \mathrm{~mm} \sim 83 \mathrm{~mm}$ (平 均 $28.1 \mathrm{~mm}$ ) であった。解剖学的部位は脾動脈 11 例、上腸間膜動 脈 4 例、総肝動脈 3 例、腎動脈 2 例、下膵十二指腸動脈 2 例、上 膵十二指腸動脈 1 例、胃大網動脈 1 例、肝内肝動脈 1 例であっ た。治療は 14 例が血管内治療を行い、11 例は手術を行った。手 術 11 例の内訳は上腸間膜動脈瘤 4 例、総肝動脈瘤 2 例、腎動脈 
瘤 2 例、脾動脈瘤 1 例、上/下膵十二指腸動脈瘤 2 例であった。治 療に伴う合併症として 1 例は肝動脈再建グラフトが閉塞して肝 限局壊死を認めた。1 例は脾膿瘍を生じた。死亡例はなく、遠隔 期再発例はなかった。

【結語】内藏動脈瘤 25 症例の治療を経験し、良好な治療成績を得 た。内藏動脈瘤の治療には手術 : 瘤切除 (再建) 術、縫縮術、結 禁術または経カテーテル的塞栓術などがある。血管内治療は手 術と比べて低侵襲であり治療効果も劣らないことから、当科の 方針としては瘤の部位により可能であれば血管内治療を第一選 択とし、重篤な臓器虚血の合併が予想される症例は手術として いる。内藏動脈瘤の治療の際には臓器虚血の問題を念頭におき、 症例ごとに治療方針を決定することが重要と考えられた。

Key words : visceral aneurysm, management of aneurysm

\section{PD-9-5内臓動脈瘤の治療ストラテジーに対する 血行力学的考察}

1 東京大学 血管外科、2 旭中央病院 外科

$\bigcirc$ 保科 克行 1 、宮原 和洋 1 、佐野 允哉 1 、木村 賢 2 、 花田 和正 1 、松浦 壮平 1 、大片 慎也 1 、大橋 雄一 1 、 福原 菜摘 1 、白須 拓郎 1 、赤井 隆文 1 、伊佐治 寿彦 1 、 高山 利夫 ${ }^{1}$

内臓動脈瘤は大動脈瘤と異なり、その破裂リスクは必ずしも瘤 径に依存しないなど数々の特徵を有する。瘤発生打よび拡張 · 破裂に至る過程には、血行力学的要素の関与を示唆するエビデ ンスが散見される。大動脈瘤に関しては構造力学的因子の関与 が主であるのと対照的である。われわれは膵十二指腸アーケー ド動脈、脾動脈、腎動脈に関して、当科での臨床データに加え、 血行力学的考察を行ってきた。下記に示したものは仮説ではあ るが、実際の瘤のデータを支持するものであることが示された。 （1）腹腔動脈狭窄・閉塞と膵十二指腸動脈瘤の関係：膵十二指 腸アーケード動脈瘤 13 例を検討し、腹腔動脈狭窄・閉塞の有 無、systemic な疾患の有無などを検討した。電気回路モデルを用 いて、腹腔動脈狭窄の程度によってアーケード血流がどのよう に変化するかをシミュレートした。(2) 脾動脈瘤と同動脈の屈曲 の関係 : 脾動脈瘤症例およびコントロール症例の CT 画像デー タから、脾動脈の中心線を抽出し屈曲率を求めた。脾動脈瘤患者 では同動脈は長く屈曲していた。また女性において平均曲率と 瘤の拡張速度に相関を認めた。また当科での 70 例を検討し、門 脈高血圧症例打よび瘤径 $20 \mathrm{~mm}$ 以上では拡張速度との相関を認 めた。しかし egg-shell 形状はそれらの因子に抑制的に働いた。 (3) 腹部大動脈瘤容積と腎血流の関係 : 0 次元電気回路モデルを 用いて、腹部大動脈瘤の大きさに応じた腎動脈血流の変化をシ ミュレートした。これらの理論と臨床データの擦り合わせの妥 当性については、議論がある。より多くの症例を重ねることで理 論の最適化が可能で、将来的に内臓動脈瘤のストラテジーに寄 与すると考える。

Key words : visceral artery aneurysm, hemodynamic

\section{パネルディスカッション 10}

\section{血管炎に対する治療戦略}

座長：中岡 良和 (国立循環器病センター研究所血管生理部) 種本 和雄 (川崎医科大学 心臓血管外科)

\section{PD-10-1 血管炎による末梢動脈閉塞の治療戦略}

東京都健康長寿医療センター 血管外科

○赤木 大輔、根元 洋光

血管炎は、基礎となる疾患が多く多彩である。一般的な特徵とし て血管炎による血行不全に対する血行再建は、内膜肥厚による 再狭窄、グラフトの不良な開存率、吻合部動脈瘤形成、炎症によ る易血栓性、ステロイド投与や免疫抑制剤投与によるハイリス クな全身状態といった問題があり、治療に苦慮することが多い。 当科では (1) どのタイミングで介入するか (2) 術前準備として 何を行っておくか (3) どの病変をどのように治療するか (4) 術 後後療法はどうするか (5) フォローアップの仕方（頻度、検査 内容など)。という問題に対し、(1) コントロール困難な疼痛、壊 死感染が拡大する場合以外はできるだけ介入を待つ（2）全身の 炎症のコントロールを優先し、できるだけ炎症が消退するまで 待つ（3）狭窄部は炎症の主座であると考え、EVTよりはバイパ スをメインに選択する。ただし、閉塞後の血行動態も予想し血行 再建プランを検討する (4) 炎症の制御、抗血小板療法に加え抗 凝固療法を積極的に考慮する（5）術後早期は 2 週間に一度血流 をチェックするという方針である。症例提示し検討を行う。

【症例】79 歳女性、慢性関節リウマチにて当センター膠原病内科フ オローアップ中。両手両足の疼痛を主訴に来院、四肢の阻血があ り入院となった。造影 CT にて下肢動脈病変のメインは下腿であ った。リウマトイド血管炎による動脈閉塞との診断でステロイド パルスと免疫抑制剤を導入し、炎症をコントロールしたのち、右 大腿-足背動脈を施行した。左下肢は腓骨動脈経由のストレート ラインがあったが、狭窄に対して EVT を行った。足部末梢は壊死 したが他院形成外科で壊死部の切断と形成を行い救肢できた。

Key words : vasculitis, revascularization

\section{PD-10-2 大型血管炎に対する生物学的製剤治療の ピットフォール}

京都大学 臨床免疫学

吉藤 元

大型血管炎は、高安動脈炎と巨細胞性動脈炎からなる。高安動脈 炎は、若年女性に好発し、全身炎症症状を伴いつつ、大動脈打よ び大動脈一次分枝の拡張または狭窄をきたし、進行すると大動 脈弁閉鎖不全、失明、大動脈瘤などの重大な合併症をきたす。病 理学的には、肉芽腫性炎症所見を認め、中膜が外方から破壊され ていき、結果的に、内腔の拡張をきたすか、あるいは、反応性に 内膜肥厚が起こり、内腔の狭窄をきたす (Yoshifuji, Mod Rheum, 2019)。ステロイド（大量～中等量）が標準治療であるが、ステ ロイドの減量中に再燃が起こりやすいため、2017 年改訂診療ガ イドラインでは慎重なステロイド漸減が推奨されている。従来、 各種の免疫抑制薬が用いられてきたが、近年、分子標的薬である 生物学的製剂が応用されるようになり、本邦では、IL-6 受容体阻 
害薬 tocilizumab (TCZ) の治験 (Nakaoka, Ann Rheum Dis, 2017) が行われ、2017 年に保険適用が大型血管炎に拡大された。TCZ は、強力かつ速効性のある抗炎症効果を示すが、バイオマーカー としての CRP は、TCZ により maskされてしまう (TCZの薬効 により著明に低下する) という問題点がある。本演題では、TCZ 投与中にもかかわらず、動脈病変が進行してしまったとされる 高安動脈炎 5 例の報告(Bredemeier, Clin Exp Rheumatol, 2012) (Liebling, Ann Rheum Dis, 2018) (Sanchez-Alvarez, Ann Rheum Dis, 2018) (Muratore, Ann Rheum Dis, 2019)について、病態を吟 味し、とりうる対策を考察する。

Key words : Takayasu arteritis, tocilizumab

\section{PD-10-3 Unmet medical needs を考慮した心疾} 患のマネージメントーIgG4 関連血管疾患の治療方針一 1 国立病院機構 金沢医療センター、 2 金沢大学医薬保健研究 域保健学系病態検査学

$\bigcirc$ 松本 康 1 、笠島 里美 2 、笠島 史成 1 、山本 宜孝 1

【目的】現在 Unmet medical needs の最たるものとして IgG4 関 連疾患 (IgG4-RD) が話題となっている. IgG4 陽性形質細胞浸 潤, 線維増生を特徵とする指定難病であり，一般にIgG4-RD に はステロイドが有効とされるが, 今回, ステロイド使用の是非に ついて遠隔成績から考察したので報告する.

【対象と方法】ステロイドを中心とする治療を行った IgG4-RD12 症例を対象とした. 平均年齢 68.8 歳, 男女比 $11: 1$, 血清 IgG4 值は平均 $634 \mathrm{mg} / \mathrm{dl}$ で, ほぼ全例 $300 \mathrm{mg} / \mathrm{dl}$ 以上の高值を示した. 発生部位は冠動脈 9 例, 腹部大動脈 3 例であった. 高容量ステロ イド治療を冠動脈 2 例, 腹部大動脈 1 例に, 瘤切除抢よび冠動脈 バイパス術の施行単独を 1 例に, 外科治療と低用量ステロイド 併用を 1 例に，低用量高容量ステロイド治療のみを 7 例にそれ ぞれ行い，その転機をもとに考察した。

【結果】冠動脈病変で高容量ステロイド治療を行った 2 例では破 裂による突然死を認めた．腹部大動脈の高容量ステロイド治療 例でも仮性瘤を形成し, 腹部ステントグラフト内抻術を施行し たが, 約 6 か月後に大動脈-十二指腸瘻で死亡した. 瘤切除打よ び冠動脈バイパス術の併施と低用量ステロイド治療を行った症 例と低用量ステロイド治療のみを行った他の 8 症例は血清 IgG4 值の低下を認め生存経過観察中である.

【結語】IgG4-RD に対する外科的治療は奏効性が高く, 容認でき る治療と考えられた。一方, 高容量ステロイド治療については, 瘤径が比較的小さいものでも破裂頻度が高く，ステロイドによ る肥厚外膜の菲薄化の可能性があり, 慎重に行うべきと考えら れた. IgG4-RD に対し，ステロイドを使用する際は，体格や活動 性, 血清 IgG4 值に合わせた低用量維持療法が推奨される. Key words : IgG4, periarteritis

\section{PD-10-4 バージャー病やバージャー病類似疾患に}

\section{対する診断治療}

育和会記念病院 循環器内科

○河原田 修身

近年では、閉塞性血栓性血管炎（thromboangiitis obliterans: TAO、バージャー病) に対する血行再建法として血管内治療の有
用性が報告されてきた。それに伴い日常診療では、血管内治療医 がバージャー病とバージャー病類似疾患を有する患者に遭遇す る機会が増えている。しかし、比較的若年であること、契煙歴が あること、下腿動脈や前腕動脈に閉塞性病変を認めることなど を根拠に安易に「バージャー病による虚血」と診断されているこ とも見受けられる。バージャー病の病態やバージャー病類似疾 患の種類は多岐にわたることから、鑑別診断と病態に応じた適 切な治療法を選択することが極めて重要である。本セッション では、バージャー病、ならびにバージャー病類似疾患として膠原 病に関連した血管炎血栓症（強皮症、結節性多発動脈炎、全身性 エリテマトーデス、血管ベーチェット、抗リン脂質抗体症候群、 好酸球性血管炎など)、骨髄増殖性疾患に対する鑑別診断と個別 化治療の実際を提示し、至適な血管診療について論じたい。

Key words : thromboangiitis obliterans, differential diagnosis

\section{PD-10-5 IgG4 関連炎症性腹部大動脈瘤に対して 外科的治療は有効か? 一ステントグラフト内挿術と 開腹手術の比較-}

${ }^{1}$ 国立病院機構金沢医療センター 心臓血管外科、2 国立病院 機構金沢医療センター 臨床検査科・病理診断科、 ${ }^{3}$ 金沢大 学 医薬保健研究域保健学系病態検査学

$\bigcirc$ 笠島 史成 1 、山本 宜孝 ${ }^{1}$ 、松本 康 ${ }^{1}$ 、川島 篤弘 2 、 笠島 里美 2,3

【目的】 IgG4 関連疾患 (IgG4-RD) は、組織の IgG4 陽性形質細胞浸 潤と線維増生、血清 IgG4 高值を特徵とする疾患群である。炎症性 腹部大動脈瘤 (IAAA) の約半数が IgG4-RD に属することを解明し たが、IgG4 関連 IAAA は臨床的に不明な部分が多く、治療指針は 確立されていない。同疾患に対するステントグラフト内挿術 (EVAR) と開腹人工血管置換術 (OSR) の有効性について検討した。 【方法】IgG4 関連 IAAA に対する EVAR（IgG4+EVAR）8例、 OSR (IgG4+OSR） 13 例、および非 IgG4 関連 IAAA に対する EVAR (IgG4-EVAR) 9 例、OSR (IgG4-OSR) 10 例の 4 群に ついて、臨床症状、血清值、大動脈周囲線維化 (PAF)、瘤径等 を後顧的に評価した。

【結果】各群の年齢、瘤径、PAF に有意差は認めなかった。術前 血清 IgG4 は、IgG4+EVAR 群と IgG4+OSR 群にて同様に上昇 していた。IgG4+OSR 群と比較して、IgG4+EVAR 群では、術後 の血清 IgG4 増加例 (5/8; p=0.006） および PAF 進行例 $(5 / 8$; $\mathrm{p}=0.027$ ） が有意に多く、術後血清 IgG4（中央值 $141 \mathrm{mg} / \mathrm{dL}$; $\mathrm{p}=0.034$ ）、PAF (中央值 $5.1 \mathrm{~mm} ; \mathrm{p}=0.016$ ）共に有意に高值であ り、また臨床症状持続例も多かった ( $=0.006) 。 I g G 4-E V A R$ 群 と比較し、IgG4+EVAR 群では、術後有意に PAF 肥厚 $(p=0.024)$ 、瘤径増加（中央值 $+13.1 \mathrm{~mm} ; \mathrm{p}=0.030 ）$ が認められた。 血清 IgG4 変化率は、PAF 変化率 $(\mathrm{R}=0.555, \mathrm{p}=0.030)$ および瘤 径 $(\mathrm{R}=0.902, \mathrm{p}=0.003)$ と正の相関を示した。

【結語】IgG4 関連 IAAA に対する EVAR は、同疾患に対する OSR や、非 IgG4 関連 IAAA に対する EVAR と比較して血清 值、PAF、症状などの改善にそしく、IgG4-RD の病態を改善さ せていない可能性がある。IgG4 関連 IAAA に対する根治的治療 としては OSR が適していることが示唆される。

Key words : IgG4-related disease, IAAA 